\title{
DEFAULT, RESCHEDULING AND INFLATION: PUBLIC DEBT CRISES IN SPAIN DURING THE $19^{\mathrm{TH}}$ AND $20^{\mathrm{TH}}$ CENTURIES*
}

\author{
FRANCISCO COMÍN \\ Universidad de Alcalá ${ }^{\mathrm{a}}$
}

\begin{abstract}
This article provides a historical overview of the factors leading up to debt crises and the default mechanisms used by governments to solve them, ranging from repudiation and restructuring to inflation tax and financial repression. The paper also analyses the Spanish governments' graduation to responsible public debt management under democracy and the last debt crisis starting in 2010. After analysing the evolution of the outstanding public debt, budget deficits, the Spanish economy's ability to borrow, the central government's debt affordability and the profile of public debt, the article concludes that the Spanish case confirms the main hypotheses of concerning international debt crises: short-term borrowing enhanced the risk of a debt crisis; insolvency problems arose when governments were unwilling or unable to repay debt; debt crises took place after large capital inflows; most outright defaults ended up being partial defaults; public debt level became unsustainable when it rose above 60-90 per cent of GDP; default trough inflation became commonplace when fiat money displaced coinage; financial repression was used as a subtle type of debt restructuring; and defaults endangered the creditworthiness of the Spanish Finance Ministry and forced disciplined fiscal policies.
\end{abstract}

Keywords: public debt, default, restructuring, inflation tax, financial repression, fiscal policy

JEL Code: E31, E4, E6, F3, F4, H6, N10, N23, N43, H63, F34

* Received 13 May 2012. Accepted 6 September 2012. I am very grateful to Pablo Martín-Aceña, Elena Martínez and María Ángeles Pons for inviting me to deliver this paper to the two conferences they organised on financial crises at the Pablo de Olavide University in Carmona (Seville) and at the Fundación Areces in Madrid and for their helpful comments. I would also like to thank the participants at these conferences for their useful suggestions and comments, especially Gerardo della Paollera. Finally, I wish to thank Leandro Prados de la Escosura, Andrés Hoyo, Javier Moreno and Joaquín Cuevas for data and valuable suggestions.

a Francisco Comín, Departamento de Fundamentos de Economía e Historia Económica, Universidad de Alcalá, Facultad de Ciencias Económicas y Empresariales, Plaza de la Victoria 3, 28802 Alcalá de Henares, Madrid, Spain. francisco.comin@uah.es 


\section{RESUMEN}

Este artículo proporciona una visión histórica de los factores que crearon las crisis de la deuda y de los métodos utilizados por los gobiernos para resolverlas: el repudio, la restructuración,el impuesto inflacionista y la represión financiera. También analiza la graduación de los gobiernos españoles en la gestión responsable de la deuda pública en la democracia.Se analiza la evolución de la deuda pública en circulación, los déficits presupuestarios, la capacidad endeudamiento de la economía española y del gobierno, así como el perfil de la deuda soberana. El artículo concluye que el caso español confirma las hipótesis principales sobre las crisis internacionales la deuda con respecto a: los préstamos a corto plazo aumentaban el riesgo de las crisis de la deuda; los impagos ocurrieron cuando los gobiernos no quisieron o no pudieron pagar la deuda;las crisis de la deuda tuvieron lugar después de grandes entradas de capital extranjero; las bancarrotas acabaron convirtiéndose en restructuraciones; la deuda soberana se hizo insostenible cuando superó el 60-90\% del PIB; la inflación se convirtió en la forma general de impago cuando el dinero fiduciario desplazó a las monedas metálicas; la represión financiera se utilizó como la forma más sutil de restructuración de la deuda; los impagos hicieron peligrar la solvencia de del Ministerio de Hacienda y obligaron a realizar políticas fiscales restrictivas.

Palabras clave: deuda pública, impago, restructuración, impuesto inflacionista, represión financiera, política fiscal

\section{INTRODUCTION}

Public debt crises occurred when public liabilities surpassed the State's ability to meet the debt burden following a period of funding budget deficits through public borrowing. Public debt could not be serviced or refinanced (because creditors believed they would not be repaid) and the government defaulted. In order to identify Spain's debt crises in the $19^{\text {th }}$ and $20^{\text {th }}$ centuries, we will commence by analysing the evolution of outstanding public debt, budget deficits, the Spanish economy's ability to borrow, the central government's debt affordability (and debt sustainability) and the profile of public debt (the weight of both short-term and external debt). In the following sections, due to the fact that the default mechanisms used by governments to resolve debt crises changed, we study the phases of the history of Spanish public debt. We focus on the episodes of default and rescheduling. When they could not meet interest payments, roll over or pay off the debt, governments declared a default that could be total (repudiation), 
or partial (restructuring). Reneging on public debt obligation was outright default. Debt rescheduling was partial default and involved reducing interest rates and/or principal, and extending debt maturity.

In the third section, we study the debt crisis inherited from the Ancien Regime and concentrate on Fernando VII's debt repudiations and the debt restructurings that Liberal governments carried out up to 1876, including those by the Finance Ministers Bravo Murillo, García Barzanallana and Salaverría. In the episodes of debt repudiations, the Monarch either did not recognise the existing debt or unilaterally stopped paying the interest. Spanish governments reneged on public debt either because of the change of political regime (absolutist restorations) or when the government was highly indebted and debt burdens became unsustainable. The debt restructurings of this phase were actually covert repudiations as they had been decided upon unilaterally by governments and imposed on the bondholders. These cases of debt rescheduling implied reducing face value, nominal interest rates or net yields and extending maturity.

In the fourth section, we analyse debt crises in Spain between 1880 and 1975. At the end of the $19^{\text {th }}$ century, restructurings of the external debt were voluntary and agreed upon with foreign investors, while in the $20^{\text {th }}$ century, the prevalence of internal debt allowed governments to both carry out debt restructurings and also use inflation tax. Consequently, in the three first paragraphs we study Camacho's arranged, voluntary debt restructuring, Fernández Villaverde's debt rescheduling and the debt consolidations that took place in the interwar period. In the fourth paragraph, we examine how governments turned to currency debasement and inflation tax as a means to expedite repudiation of domestic debt. This mechanism of currency debasement had been used since the First World War and, in particular, during the Franco Regime. Inflation tax solved debt crisis because inflation reduced the real value of the existing stock of debt and of its service burden. The Franco Regime also resorted to financial repression in order to finance budget deficits and extra-budget public investments in privileged conditions (out of the market). Financial repression was used in Spain to expand domestic debt markets. Thanks to the obligatory investment coefficients banks and savings banks had to lend large amounts of their assets to the general government and stateowned firms. Thereby Franco's finance ministers enjoyed lower interest rates than on the capital market and citizens were forced to hold low interest bank accounts.

Finally, in the fifth section, we analyse the Spanish governments' graduation to responsible public debt management under democracy. In the first paragraph, we focus on the transition from repudiation methods during the Franco Regime (printing money by the Bank of Spain and financial repression) to the democratic governments' fiscal responsibility. This graduation from being a serial defaulter was boosted by the financial commitments adopted when Spain 
became a member of the European Union (1986). In the second paragraph, we study how this fiscal responsibility did not prevent Spain from suffering a new debt crisis created by the economic recession and the contagion of the Greek debt crisis in 2010.

\section{A SECULAR EVOLUTION OF DEBT, INFLATION, DEFICITS, DEFAULTS AND THE BURDEN OF THE DEBT SERVICE: THE DEBT CRISIS INDICATORS}

In order to identify public debt crises and to estimate the consequences of defaults, we will analyse the following series: (1) the level of real public debt, (2) the budget deficit/GDP ratio, (3) the ratio of public debt to GDP, (4) the debt affordability or debt burden - which is the percentage of debt service in total budget expenditures - and (5) the percentage of external and shortterm debt in total outstanding public debt.

\subsection{The level of real public debt: covert repudiation caused by inflation}

Until 1983, outstanding public debt (central government debt), in real terms of pesetas of 1913 (Figure 1), did not surpass 20,000 million. After that, real public debt skyrocketed to 124,626 million pesetas in 1999. Before 1983 (see Figure 2), the peaks of real public debt (1878, 1902, 1935 and 1973), which identify the main debt crises in modern Spain can be seen clearly. The peaks of existing public debt before 1983 were around 14,000 million pesetas of 1913. We must include the severe debt crisis prior to 1850 that is not reflected in the figure.

Spain exited these debt crises by reducing the stock of public debt by resorting both to debt restructurings and to inflation tax. First, after the Bravo Murillo debt rescheduling, the level of public debt was brought down between 1850 and 1855. After having been at a standstill for a decade, public debt grew notably between 1864 and 1878, thereby generating another debt crisis. Real public debt fell from this ceiling to a low in 1886. The greatest reduction occurred in 1882 and 1883, thanks to the Camacho debt restructuring.

Second, between 1886 and 1901, outstanding public debt grew, especially between 1898 and 1901, as a consequence of waging the colonial war in Cuba. This new debt crisis was resolved thanks to Fernández Villaverde's fiscal consolidation, which restructured the debt and obtained budget surpluses that allowed for paying back part of the outstanding Treasury bonds. Thanks to this measure, existing public debt fell between 1902 and 1904. Between 1909 and 1920, the real stock of debt dropped sharply thanks to the inflation process generated by the budget deficits that were monetised (Figure 3). 
FIGURE 1

REAL PUBLIC DEBT (MILLION PESETAS OF 1913) (1850-2000)

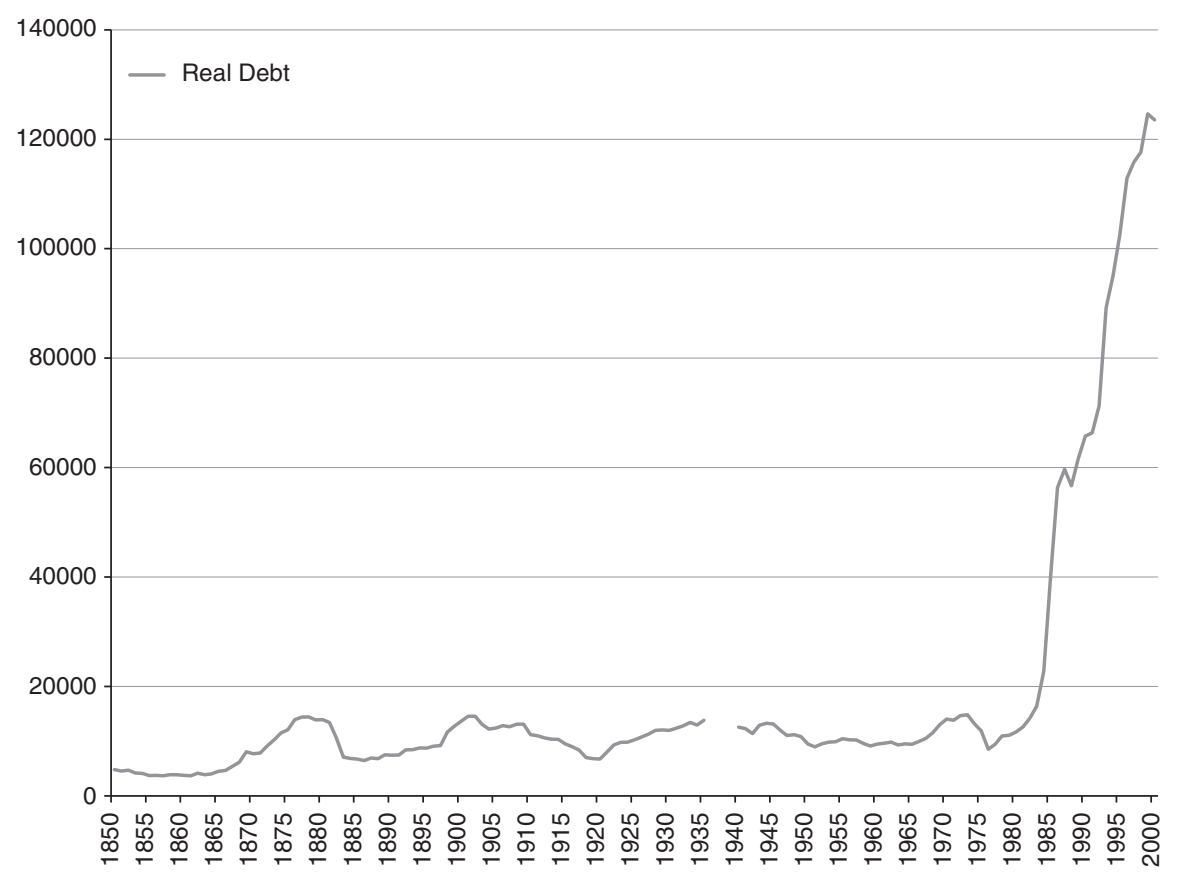

Source: Comín and Díaz (2005) and Prados de la Escosura (2003).

At the beginning of the $20^{\text {th }}$ century, by reducing the debt's real value, Spanish governments exhausted domestic bondholders. Annuitant euthanasia also occurred in Spain.

Third, real public debt grew rapidly between 1920 and 1935 because of budget deficits mainly caused until 1925, by the war in Morocco. During the Civil War, public debt increased for both the republican government as well as for Franco's army funding. War funding was carried out by the respective Banks of Spain (the national bank and the republican bank), so there were no public debt issues to finance the Civil War, although Franco did receive loans from other fascist governments (Comín 2008; Comín and López 2008; Martorell and ComÚn 2008). Real public debt fell between 1940 and 1951 in the post-war period. This fall was initially influenced by Larraz's debt rescheduling; however, the descent of the level of real public debt after 1944 was caused by a highly inflationist process (Figure 3). Franco honoured the foreign debt Hitler and Mussolini had provided but hurt holders of domestic debt on the national side, and defaulted on the republican liabilities issued during the war. 
FIGURE 2

REAL PUBLIC DEBT (MILLION PESETAS OF 1913) (1850-1982)

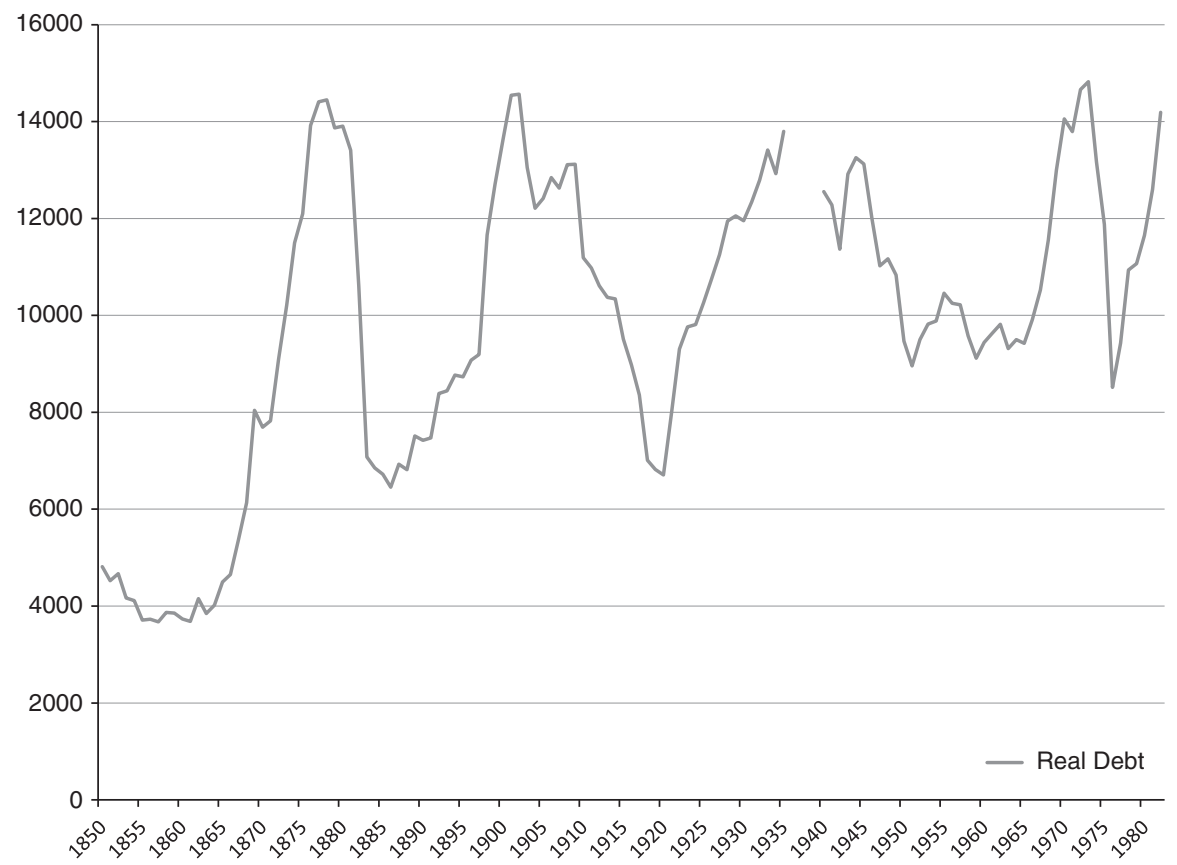

Source: See Figure 1.

Fourth, real public debt stalled between 1952 and 1965 only to increase later until 1973. Subsequently, deficit monetisation and inflation reduced the real value of public debt. For a second time, Franco hurt those who had financed budget deficits with another partial default caused by inflation (Figure 3). Finally, budget deficits during the transition to democracy increased real public debt until the 2008 public debt crisis.

The inflationary tax acted when the inflation rate exceeded 5 per cent for a certain period of time, according to Reinhart and Rogoff (2009). This only happened in the $20^{\text {th }}$ century (Figure 3 ). First, during the First World War, the inflation rate almost reached 15 per cent, when the monetary supply yearly rate of growth hit 21 per cent. Second, between the Civil War and 1992, the inflation rate exceeded 5 per cent, except for the years after the Stabilisation Plan (1960-1961). The inflation rate was particularly high (above 10 per cent) during the autarchy period (1939-1958) and the transition to democracy (1973-1984), as was the case of the rate of growth of the monetary supply. Inflationary tax, therefore, was used extensively during the 
FIGURE 3

INFLATION RATE AND M2 (PERCENTAGE RATE OF GROWTH MOVING AVERAGES THREE YEARS)

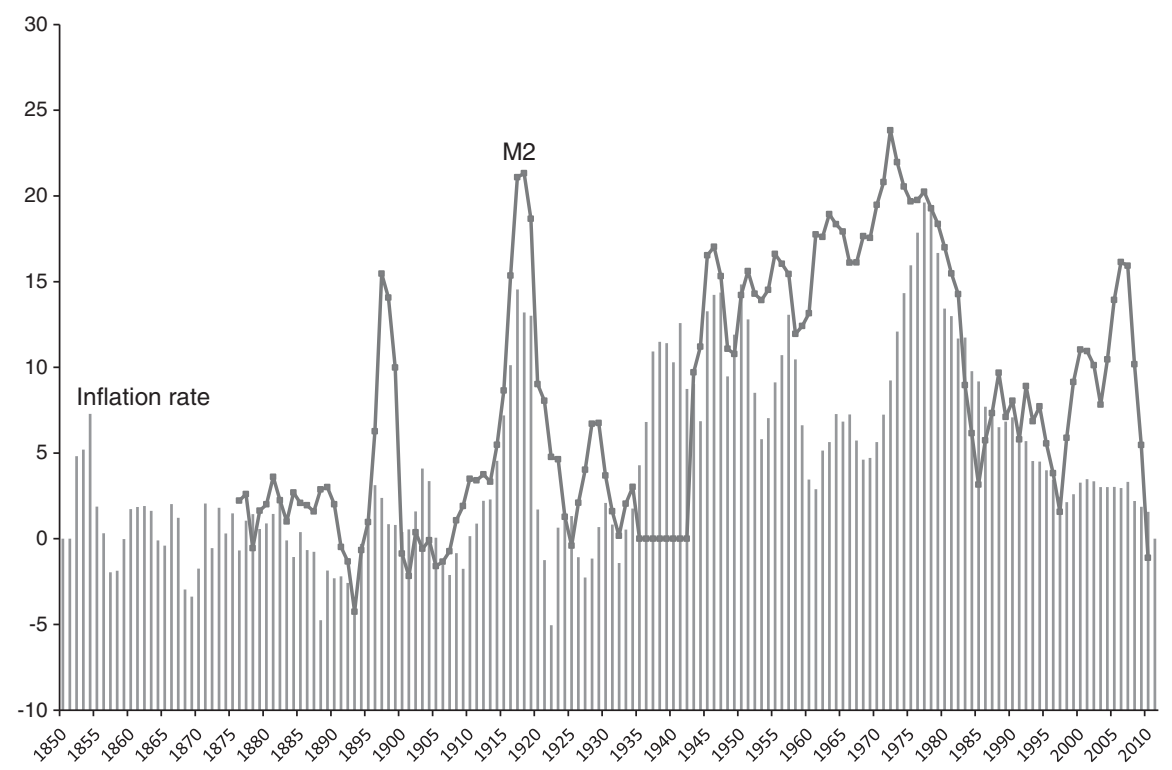

Source: Martín-Aceña and Pons (2005), Prados de la Escosura (2003), Instituto Nacional de Estadística and Banco de España.

Franco regime and the transition to democracy, before joining the European Union $^{1}$. These high and persistent inflation rates reduced the real value of outstanding public debt (Figure 1).

The inflationary tax also eroded the real value of government bond yields. It is virtually impossible to calculate the average nominal interest rate of public debt over two centuries, given the variety of securities. To solve this problem the official interest rate on loans from the Bank of Spain to private banks against the collateral of public debt is used as a proxy. As shown in Figure 4 , through the $19^{\text {th }}$ century real debt interest rates were rarely negative, while in the $20^{\text {th }}$ century negative interest rates predominated in two periods: during the First World War (1915-1920) and between 1936 and 1984. In fact, during the Franco regime the years when real interest rates on public debt were positive were exceptional, despite the growth of nominal interest rates above 5 per cent between 1966 and 1998; in the 1977-1993

1 Reinhart and Rogoff (2010) point out that in emerging markets and in some advanced economies, there is a positive relationship between increases in inflation and those in public debt. 
FIGURE 4

INTEREST RATES ON THE BANK OF SPAIN'S LOANS AGAINST PUBLIC DEBT AS COLLATERAL (1874-2010)

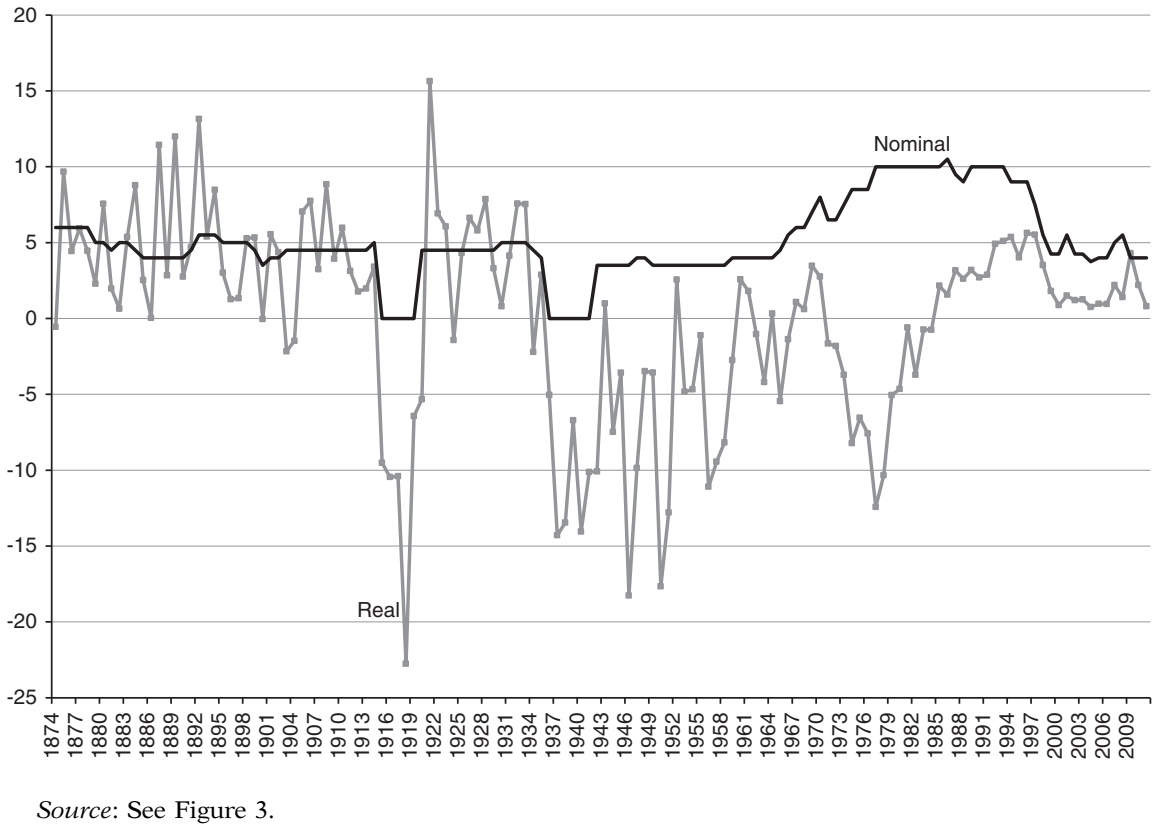

period, nominal interest rates even reached 10 per cent. As of 1985, the responsible management of public debt and the control of inflation made it possible for real interest rates to become positive again.

\subsection{The origin of public debt crises: budget deficits}

The origin of public debt crises was to be found in the large budget deficits. Figure 5 shows that Spain's debt crises arose when the state's budget deficit neared 6 per cent of GDP. First, after the Bienio Progresista (18541855), the budget balance reached a trough at -1.2 per cent of GDP in 1856. This level was insufficient to unleash a debt crisis. Second, the deficit levels (5.6 per cent in 1870) reached during the Sexenio Democrático (1868-1874) and the 10 years' war in Cuba (1868-1878) triggered a debt crisis that was solved through defaulting on debt interest payments, which reduced the budget deficit in the 1870s.

Third, budget deficits were small up to 1892 (a trough of 1.3 per cent of GDP in 1888), and they did not bring about debt crises. On the contrary, the 
FIGURE 5

GOVERNMENT BUDGET BALANCE TO GDP (PERCENTAGES) (1850-2013)

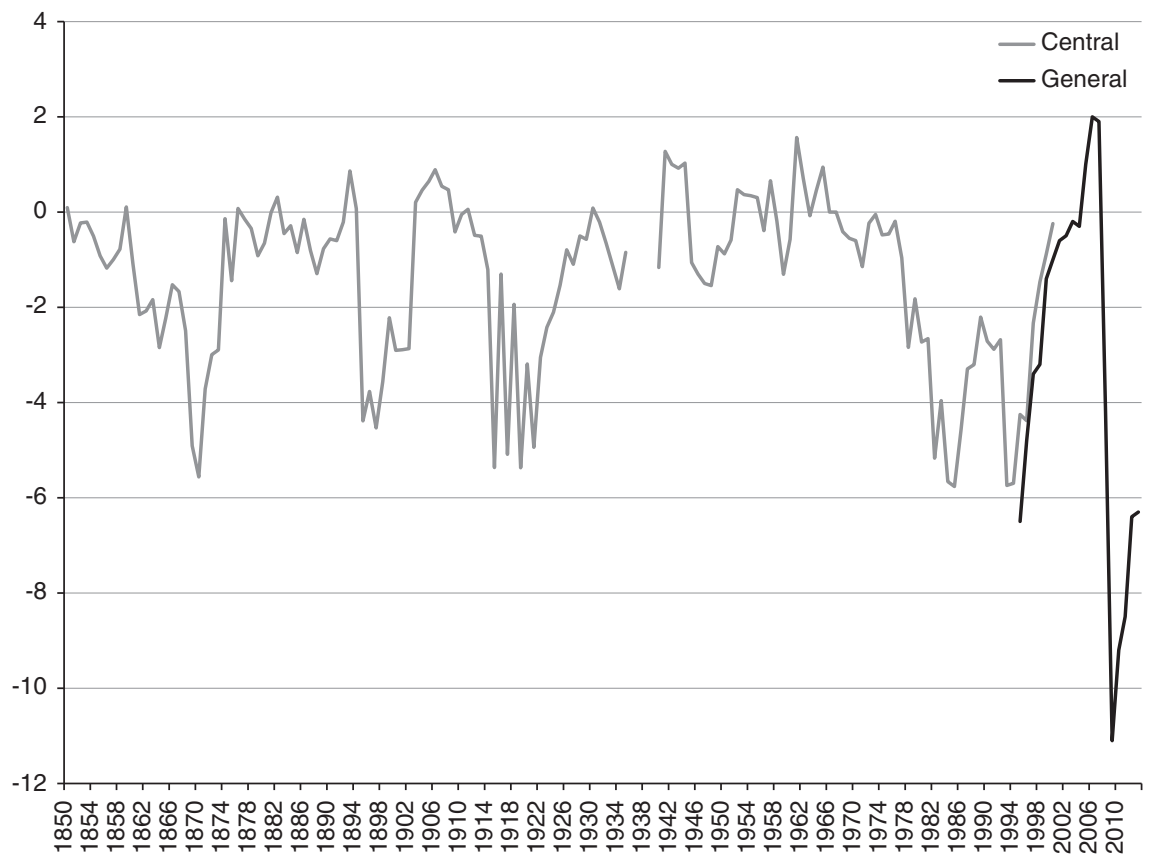

Source: Comín and Díaz (2005), Prados de la Escosura (2003), Ministerio de Hacienda and Instituto Nacional de Estadística.

large budget deficits generated by the war in Cuba (Spanish War, 1895-1898: 4 per cent of GDP) generated a new public debt crisis in Spain. Fourth, after the 1903-1911 balanced budget period, public deficits reached 5 per cent of GDP, during the period 1915-1921, partially caused by the war in Morocco, triggering another public debt crisis.

Fifth, budget deficits during the Civil War resulted in the post-Civil War public debt crisis. After the Franco regime paid the arrears of the war, budget deficits were infrequent and small (1.3 per cent of GDP in 1959 and 1.1 per cent in 1971). Apparently, there were neither fiscal crises nor explicit public debt crises under the dictatorship because Franco's governments resorted to two other unorthodox methods of public debt default: financial repression and inflation tax (see Reinhart and Rogoff 2009). First of all, during the dictatorship, banks and savings banks had to finance the economic growth policy directly as well as the social and education policies, which prevented increases in public spending and budget deficits (Martín-Aceña and Comín 1991; Comín 2007). Second, Franco resorted to inflation tax to liquidate 
his debts. Those who held bank deposits, bank notes and public debt were the losers of this unorthodox financial policy during the dictatorship.

Sixth, through the democratic period there were two debt crises whose origin can be found in budget deficits: the first debt crisis took place during the transition to democracy period up to 1985 and the second was in the economic recession of 1993 and 1994. Under democracy, the central government's budget deficit surpassed 2.0 per cent of GDP during the 1978-1997 period, reaching its ceiling in 1985 (5.8 per cent of GDP) and in 1993 (5.7 per cent). The debt crisis of 1993-1994 was resolved in an orthodox manner thanks to the policy of monetary convergence on the way to the establishment of the euro. The central government's budget deficits diminished from 1994 onwards until reaching budgetary balance in 2000. The general government's budget deficit was reduced from 6.5 per cent of GDP in 1993 until reaching a budget surplus of 1.9 per cent in 2007. Seventh, nonetheless, the great recession increased general government's budget deficit to 4.2 per cent in 2008 and to 11.1 per cent in 2009. Although the government took its time to react, the change in economic policy in May 2010, after the contagion by the Greek debt crisis, allowed for a budget deficit reduction to 9.2 per cent of GDP. The European commission estimated that Spain would fail to reduce its budget deficit, which would reach 6.4 of GDP in 2013.

\subsection{The Spanish economy's ability to sustain its public debt}

According to Reinhart and Rogoff (2009), public debt becomes unsustainable when it reaches 60-90 per cent of GDP ${ }^{2}$. The level of tolerable public debt depends on several factors: the existing level of debt, the current public budget position, interest rate levels, the debt maturity profile, the weight of external and short-term debt and the ability of the government to generate additional tax revenues, which depends on the features of the tax system and the actual and expected rate of economic growth. The public debt/GDP ratio (Figure 6) shows the cycles of the Spanish economy's ability to make debt payments.

The first cycle covers the period from Bravo Murillo's restructuring to that of Camacho. In its first phase, between 1850 and 1863, the public debt to GDP ratio dropped from 91.7 per cent to 58.5 per cent. In its second phase, from 1864, public debt increased to 168.9 per cent of GDP in 1876. Between 1868 and Camacho's debt restructuring in 1882, Spain was a highly indebted country (debt/GDP ratio higher than 100 per cent) and the public debt became unsustainable. The debt crisis was solved by the rescheduling implemented by Finance Minister Camacho. This restructuring brought outstanding public debt down to 69.9 per cent of GDP in 1886.

${ }^{2}$ Actually, Reinhart and Rogoff (2009) point out that the threshold of public debt intolerance «depends heavily on a country's record of default and inflation». Reinhart et al. (2012) characterise «major public debt overhang episodes» by «public debt to GDP levels exceeding $90 \%$ for at least five years». 
FIGURE 6

GOVERNMENT DEBT/GDP RATIO (PERCENTAGES) (1850-2013)

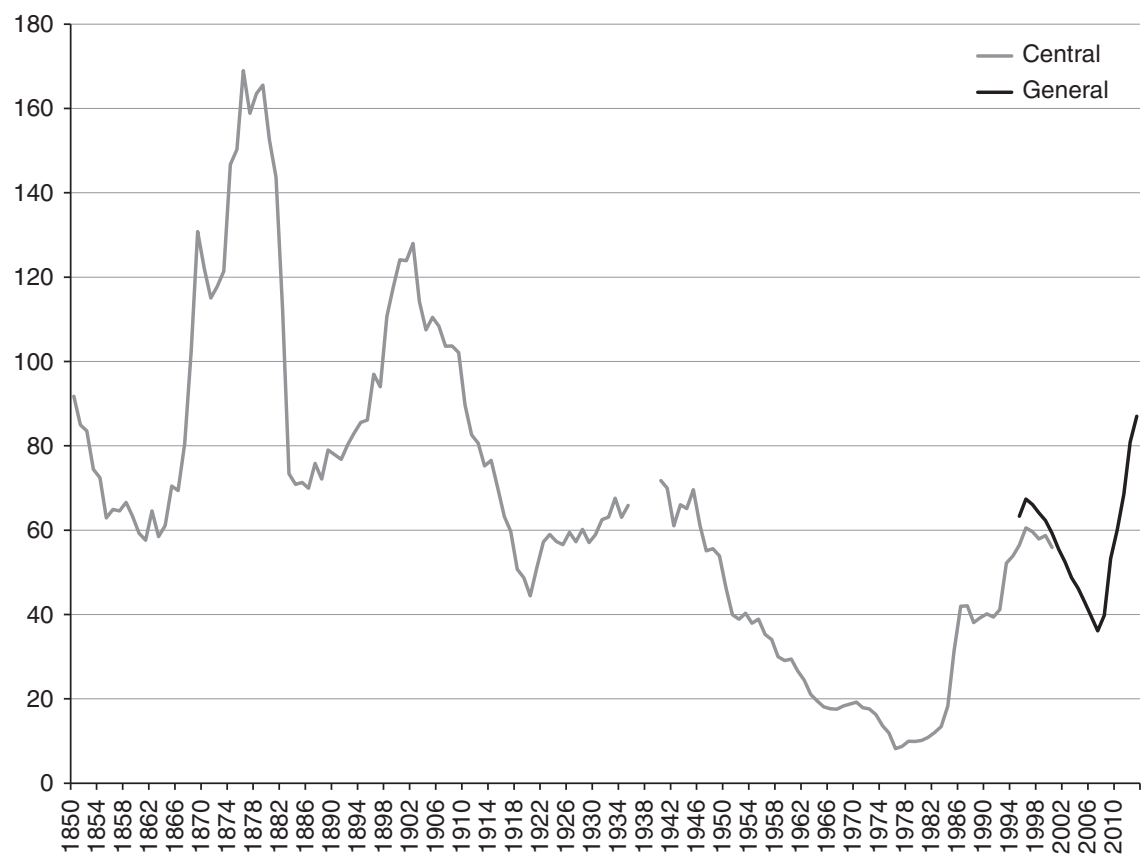

Source: See Figure 5.

The second cycle covers the period between 1890 and 1920. Once the effects of Camacho's rescheduling had passed, public debt increased once again reaching 127.9 per cent of GDP in 1902. Between 1896 and 1909, the debt/GDP ratio surpassed 90 per cent, a percentage that indicates both an unsustainable public debt and a high probability of default. This debt crisis was solved by fiscal consolidation, debt restructuring and inflation tax. Fernández Villaverde's 1899 fiscal austerity and debt restructuring together with the inflation tax introduced following the First World War reduced the public debt/GDP ratio to 44.4 per cent in 1920. During the interwar period there was no public debt crisis since the debt/GDP ratio never rose above 67.6 per cent (the figure reached in 1933). Therefore, public debt was tolerable during the Great Depression in Spain just as there was no banking crisis (Comín 1988, 2011; Martín-Aceña 2004).

The third cycle covers the period of Franco's regime. In 1940, central government debt was 71.8 per cent of the GDP. This low percentage, after having waged a Civil War, can be explained by the fact that both armies had borrowed from the Bank of Spain and, in the case of Franco, from other 
fascist governments too. These borrowings did not involve the issue of securities of public debt. On top of that Franco repudiated the liabilities issued by the republican government during the Civil War, including bills (Martín-Aceña 2004). Neither of the armies issued public debt because budget deficit was monetised. Monetary financing through currency issuance by the Bank of Spain initiated a powerful inflationary process, which reduced the real value of the public debt, as we have seen. The absence of bond issues during the Franco regime and the economic growth of the 1950s and 1960s reduced the public debt/GDP ratio to 8.2 per cent in 1976. During the Franco regime there was no formal public debt crisis.

The fourth historical public debt cycle took place under democracy. The public debt/GDP ratio grew from 13.4 per cent to 60.5 per cent of GDP between 1983 and 1996. These percentages were sustainable and ruled out any formal public debt crisis during the democratic period, despite the 1992-1993 fiscal crises when the debt/GDP ratio increased from 41 per cent to 52 per cent in 1993. Afterwards, the general government's debt to GDP ratio decreased from 67.4 per cent to 36.1 per cent between 1996 and 2007. When the international financial crisis broke out in 2007 there was no public debt crisis in Spain. Quite the contrary, the solvency of Spain's Treasury was outstanding. Nevertheless, after 2008, the existing stock of public debt reached 60.1 per cent of GDP in 2010. The level of public debt was tolerable since Spain almost met the criteria of the Growth and Stability Pact of the Eurozone. Despite this, the Kingdom of Spain's risk premium increased due to the contagion of the debt crisis in other peripheral European countries. The reason for this was that the level of debt tolerance of European countries (including Spain and Italy) was reduced due to the political conflicts unleashed between Eurozone countries, market speculation against the euro and the depressing economic growth perspectives of Europe and Spain. This explains the fact that the public debt/GDP ratio will reach 87.0 per cent in 2013, according to European Commission estimates.

\subsection{Debt affordability: the ability of government to service its debt}

The question here is whether public debt can be serviced by the government. Debt burden (the percentage of debt servicing in total budget spending) is also known as debt affordability and shows whether the Treasury can afford its debt burden (Figure 7). The historical cycles revealed by the evolution of debt affordability coincide with those previously analysed. Reinhart and Rogoff (2009) pointed out that there were five large default cycles in the world; periods when many countries suffered profound foreign debt crises ${ }^{3}$.

3 The first international debt crisis cycle occurred during the Napoleonic wars. The second cycle took place between 1820 and 1840 when half of the countries in the world defaulted (among them, all of the recently created Latin American countries). The third cycle started around 1870 and lasted for two decades. The fourth international foreign debt crisis cycle started with the Great 
FIGURE 7

DEBT SERVICING/BUDGET SPENDING RATIO (PERCENTAGES)

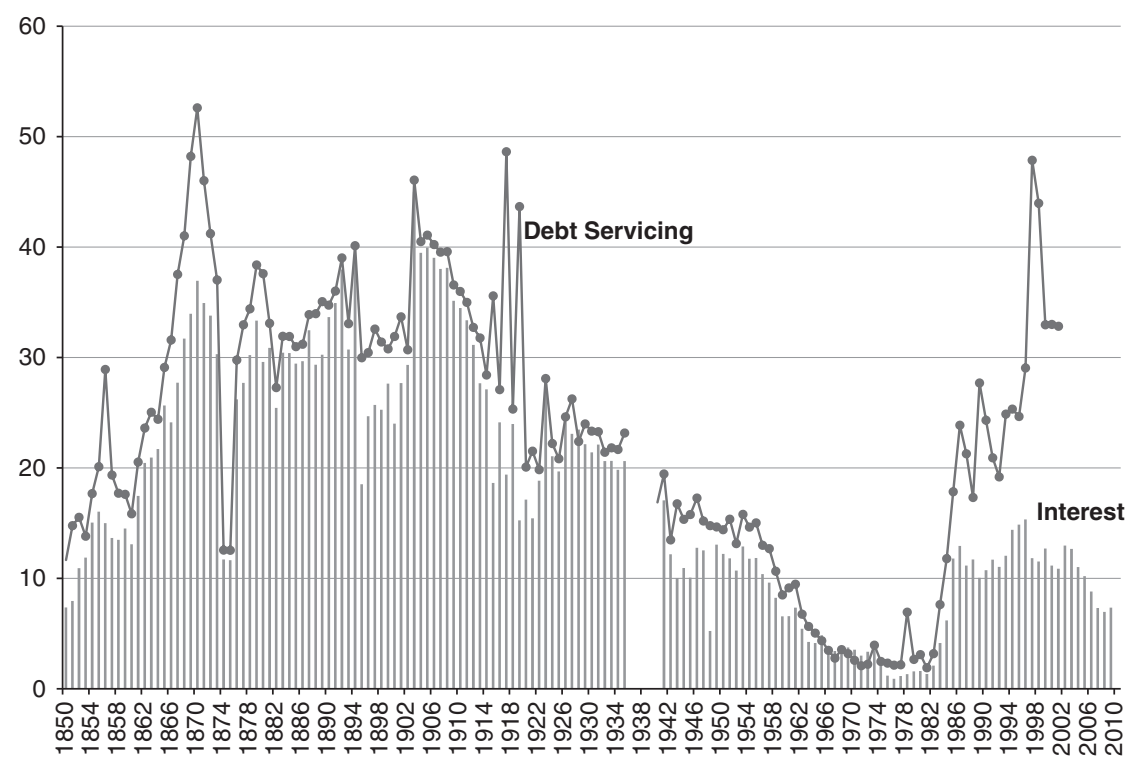

Source: Comín and Díaz (2005).

Spain shared the severe global debt crises, with the exception of the international debt crisis cycle of 1930-1950.

First cycle: After Bravo Murillo's debt restructuring, the debt burden/ public spending ratio grew from 11.6 per cent to 52.6 per cent between 1850 and 1870. The public debt burden became unsustainable generating a debt crisis that led to a default on debt interest payments, which explains the fact that in 1874-1875 debt servicing fell to 12.5 per cent of budget expenditures. After the restoration of the Bourbon monarchy, debt interest had been paid out partially since 1876 , and debt servicing grew from 29.7 per cent of budget spending to 38.4 per cent in 1879 . Once again, the public debt level became unsustainable and the State could not service such large amounts of debt interests and repayments. The gap between debt servicing and interest

\footnotetext{
(F'note continued)

Depression and lasted until the beginning of the 1950s. The fifth cycle of debt default includes the debt crisis of the 1980s and 1990s. Virtually no country experienced a debt crisis in the period 20032008. The only precedent for this debt quietness was the two-decade period that preceded the First World War when the gold standard was in effect. We must add a sixth period to Reinhart and Rogoff's periodisation; one that affects the debt crisis that was sparked in peripheral Europe in 2010. See Figure 5.1 by Reinhart and Rogoff (2009).
} 
FIGURE 8

STRUCTURE OF PUBLIC DEBT (PERCENTAGES) (1850-2001)

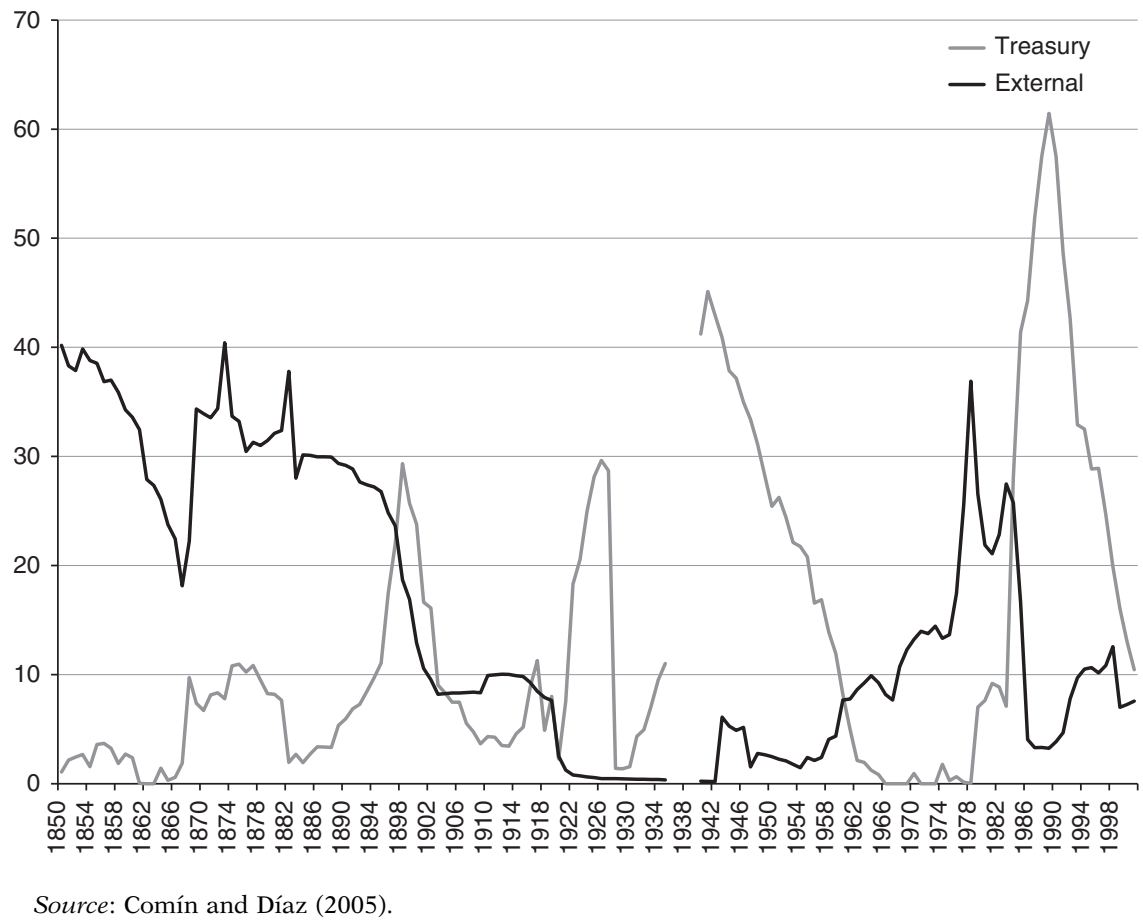

payments on the debt grew when the share of short-term debt increased (Figures 7 and 8).

Second cycle: Camacho's restructuring reduced the debt servicing/budget expenditure ratio to 27.3 per cent in 1882 . This debt rescheduling avoided the risk of insolvency of the Treasury but it did not solve the Spanish debt problems because debt servicing continued to be unaffordable. In fact the debt burden continued to grow reaching 40.1 per cent of public spending in 1894. The percentage drop in 1895 was due to the remarkable increase in budget spending to finance the Spanish War in Cuba and the Philippines by issuing colonial debts. When Spain lost the war with the United States in 1898 , the Spanish government had to assume those colonial debts as stipulated in the Treaty of Paris, which skyrocketed debt servicing to 46 per cent of budget expenditures in 1903. The fiscal consolidation policy and Fernández Villaverde's debt restructuring reduced the debt servicing/public spending ratio to 28.4 per cent in 1914. The budget deficits during the First World Ward pushed this ratio to another peak of 48.6 per cent in 1917, making the debt 
burden unaffordable once again. The inflation tax and public debt consolidations of Alba (1917) and La Cierva (1919) all helped reduce debt burden on budget spending to 20.1 per cent in 1920 .

Third cycle: During the interwar period the debt servicing/budget expenses ratio decreased from 28.1 per cent in 1923 to 21.4 per cent in 1932 , due mainly to Calvo Sotelo's debt consolidation (1927). These high percentages show that there were fiscal problems in this period. Nonetheless, as we have seen, public debt was affordable and there was no threat of an explicit debt crisis.

Fourth cycle: The debt burden was tolerable during the Franco regime. Between 1941 and 1975, the State could afford to service its debt, which fell from 19.4 per cent to 2.3 per cent of budget spending. This ratio confirms that there was no formal debt crisis in Spain during the dictatorship.

Fifth cycle: During the democratic period debt burden grew from 1.9 per cent to 47.8 per cent between 1981 and 1997. Consolidation of short-term debt reduced this ratio to 32.9 per cent in 1999. Thanks to the low levels of public debt inherited from the Franco regime, the debt servicing/budget spending ratio oscillated between 10 per cent and 15 per cent in the period 1985-2005. This percentage was sustainable and did not pose problems for the Ministry of Finance. The fiscal consolidation policy required when Spain entered the Monetary Union reduced debt burden, and borrowing costs were only 7.3 per cent of budget expenditures in 2007-2009. This reveals that the Spanish State could afford its public debt interest payments at the beginning of the great recession. The debt burden was tolerable and this indicator does not suggest the presence of a debt crisis in Spain in 2009. However, the growing public debt/GDP ratio, public debt interest rates and the proportion of short-term debt will increase the debt servicing/public spending ratio, making the debt burden unaffordable once again.

\subsection{The profile of public indebtedness during the crisis: external and short-term debt}

Debt crises changed the structure of public debt, reducing external debt and increasing short-term debt. The subsequent debt restructurings reduced both external and short-term debt. In the first place, debt crises and rescheduling tend to reduce the weight of external debt, a situation which was more important in the $19^{\text {th }}$ than in the $20^{\text {th }}$ century. In Spain, the level of external debt was high until 1895, surpassing 26.8 per cent of the total (Figure 8).

A debt crisis can explode when a country has resorted to an excess of external debt (issued in foreign currency), because it can lack sufficient foreign currency to honour its interests and payments. This was the case of Spain before 1850 and that which led to the Bravo Murillo rescheduling. After this covert default, external debt decreased from 40.2 per cent to 18.1 per cent 
between 1850 and 1867. Given that the Bank of Spain refused to grant loans to the Treasury and that the foreign stock exchanges were closed to the Spanish securities, Bravo Murillo and the finance ministers who followed resorted, from 1852, to the Caja General de Depósitos (General Savings Bank), which siphoned funds from the savings banks to the Treasury (it was the first use of financial repression in Spain).

However, during the Six-Year Period, liberal governments once again resorted heavily to foreign borrowing. In fact, in 1868, Finance Minister Laureano Figuerola closed down the Caja General de Depósitos and once again the Treasury started issuing external debt, which recovered to 40.4 per cent of the total debt in 1873 . Subsequently, the interest payments in foreign currency of external public debt grew. The debt crisis of the Six-Year Period and Camacho's debt rescheduling in 1882, reduced the percentage of external debt to 28 per cent in 1883 . Given that Spain maintained a bimetallic standard and that silver coins were depreciating, Camacho decided to ensure payment of external debt interests in gold. This led to a rapid descent of the gold reserves, which in 1883 obliged the authorities to suspend the convertibility of the peseta to gold. At this point, Spaniards started buying Spanish external debt because this ensured higher yields given that the interest was paid in gold, in Paris. In the future, this would allow the Finance Minister Fernández Villaverde to carry out a default of the external debt owed by Spanish citizens.

In fact, the debt crisis brought about by the war in Cuba and the demands that the affidavit of Fernández Villaverde's rescheduling made on those Spaniards who had external debt, reduced its relevance from 26.7 per cent to 8.2 per cent between 1895 and 1903 . The greater weight of the domestic debt allowed governments to implement inflation tax thereafter. When Villaverde restructured the debt in 1900, he demanded that Spanish external bondholders sign an affidavit so that their external securities would be legally converted into domestic debt. This explains the sharp drop of the external debt in the early years of the $20^{\text {th }}$ century. The current account surpluses during the First World War made Spanish foreign investments possible. Spaniards bought external debt in foreign hands that was automatically transformed into domestic debt. In this way the volume of the external debt was reduced to only 1.2 per cent of the total in 1921. External public debt became irrelevant.

During the Civil War, Franco's army resorted to foreign loans but this is not reflected in the public debt statistics. Besides, Franco paid off this foreign debt quickly in the post-war period. The foreign funding of Franco's army increased external debt to 6.1 per cent in 1943.

After the 1959 Stabilisation Plan and openness, external debt became significant again growing from 7.6 per cent in 1960 to 13.3 per cent in 1974 . Nevertheless, it grew even more following the subsequent foreign liberalisation carried out by the democratic regime, when external debt reached a 
peak of 36.9 per cent of the total in 1978. Later, external debt fell below 10 per cent of the total, and although the 1990s saw recuperation, the high levels of the $19^{\text {th }}$ century were never reached again. After a subsequent and extremely sharp drop due to the debt crisis in the democratic period, the external debt recovered after Spain became a member of the European Union, however it was only 7.5 per cent in 2001. External public debt was not a problem during the $20^{\text {th }}$ century.

In the second place, in contrast, the short-term debt (Treasury bills) increased during the debt crisis because lenders did not grant long-term loans to countries with fiscal difficulties given the uncertainty and the risk this implied. To solve the debt crisis, the restructurings consolidated the short-term debt, extending the maturity dates of the bills. The high percentage of Treasury bills signals the ensuing debt crises in Spain (Figure 8). First, between 1868 and 1878, the Treasury's debt was around 10 per cent of the existing debt; its volume was reduced to 2 per cent in 1882 thanks to Camacho's restructuring. Second, in the period between 1895 and 1903, the short-term debt reached 29.3 per cent in 1898; the following year, Fernández Villaverde restructured the debt, decreasing its importance to 3.6 per cent in 1909. Third, between 1922 and 1926, Spanish governments issued a large amount of short-term debt reaching 29.6 per cent in 1926; its volume was reduced to 1.3 per cent in 1928 thanks to Calvo Sotelo's consolidation of short-term public debt. Fourth, during the Civil War and the post-civil war period a large quantity of short-term debt was issued reaching a peak in 1941 (45 per cent of the total). Subsequently, Treasury bills were reduced to 2 per cent of the total in 1962 thanks to Larraz's restructuring and the pay off of the bills. In the fifth place, in the period of the transition to democracy, from 1984 onwards, a large amount of Treasury bills was also issued - making up 61.4 per cent in 1989.

To sum up, Table 1 includes the indicators of the main public debt crises in Spain during the $19^{\text {th }}$ and $20^{\text {th }}$ centuries. Although no data are available before 1849, the Spanish government was in permanent default during the first half of the $19^{\text {th }}$ century. This explains why all indicators of debt crises show a peak in 1850. Bravo Murillo's debt rescheduling cut all the series by 24-49 per cent, reaching a low in 1860 . The second public debt cycle began in the period 1861-1873 when budget deficits surpassed 20 per cent of GDP, and a public debt peak was reached in 1876. The debt reschedulings of Salaverría and Camacho brought down the level of debt to the low of 1886 (58 per cent) and the debt burden (71 per cent). The third cycle began with the budget deficits of 1895-1902 and ended in 1919 due to the Fernández Villaverde's debt rescheduling and the inflationary tax, with reductions of the debt levels of more than 50 per cent. The fourth cycle occurred during the Franco regime, when inflationary tax reduced the public debt/GDP ratio by almost 90 per cent between 1940 and 1976 and brought down the real public debt interest rate to less than -5 per cent. 
TABLE 1

PUBLIC DEBT CRISIS IN SPAIN (1850-2012)

\begin{tabular}{|c|c|c|c|c|c|c|c|c|}
\hline Ratio & $\begin{array}{c}\text { Duration } \\
\text { and depth }\end{array}$ & $\begin{array}{c}\text { Bravo } \\
\text { Murillo }\end{array}$ & Camacho & $\begin{array}{l}\text { Fernánd } \\
\text { and infl }\end{array}$ & $\begin{array}{l}\text { Villaverde } \\
\text { onary tax }\end{array}$ & $\begin{array}{l}\text { Inflationary } \\
\operatorname{tax}\end{array}$ & $\begin{array}{l}\text { Inflationary } \\
\operatorname{tax}\end{array}$ & Euro \\
\hline \multirow[t]{2}{*}{ Outstanding debt/prices } & Peak-trough & $1850-1855$ & $1878-1886$ & 1901-1919 & & $1944-1950$ & $1972-1976$ & 1999-2006 \\
\hline & Fall & $24 \%$ & $57 \%$ & $53 \%$ & & $28 \%$ & $41 \%$ & $25 \%$ \\
\hline \multirow{2}{*}{$\begin{array}{l}\text { Outstanding debt/fiscal } \\
\text { revenues }\end{array}$} & Peak-trough & $1849-1860$ & $1878-1886$ & $1901-1921$ & & 1940-1976 & & $2002-2006$ \\
\hline & Fall & $48 \%$ & $60 \%$ & $55 \%$ & & $89 \%$ & & $29 \%$ \\
\hline \multirow[t]{2}{*}{ Budget deficit/PIB } & Period & & $1861-1873$ & $1895-1902$ & $1915-1922$ & & & $1982-2006$ \\
\hline & Level & & $2.8 \%$ & $3.3 \%$ & & & & $4.1 \%$ \\
\hline \multirow[t]{2}{*}{ Outstanding debt/PIB } & Peak-trough & $1850-1860$ & $1876-1885$ & $1902-1920$ & & 1940-1976 & & 1996-2007 \\
\hline & Fall & $35 \%$ & $58 \%$ & $65 \%$ & & $89 \%$ & & $34 \%$ \\
\hline \multirow{2}{*}{$\begin{array}{l}\text { Debt servicing/fiscal } \\
\text { revenues }\end{array}$} & Peak-trough & $1856-1859$ & $1870-1882$ & $1897-1913$ & $1917-1920$ & $1946-1970$ & & $1997-2006$ \\
\hline & Fall & $49 \%$ & $71 \%$ & $30 \%$ & $29 \%$ & $3 \%$ & & $38 \%$ \\
\hline \multirow{2}{*}{$\begin{array}{l}\text { Real public debt interest } \\
\text { rate }\end{array}$} & Period & & $1887-1896$ & & 1916-1919 & $1942-1959$ & $1972-1983$ & \\
\hline & Level & & $<0$ & & $<-5 \%$ & $<-5 \%$ & $<-5 \%$ & \\
\hline \multirow{2}{*}{$\begin{array}{l}\text { External public debt/ } \\
\text { total debt }\end{array}$} & Period & $1850-1888$ & & & & & 1977-1985 & $2000-2012$ \\
\hline & Percentage & $>30 \%$ & & & & & $>20 \%$ & $>40 \%$ \\
\hline
\end{tabular}


TABLE 1 (Cont.)

\begin{tabular}{|l|l|l|c|c|c|c|c|c|}
\hline $\begin{array}{l}\text { Floating public debt/ } \\
\text { total debt }\end{array}$ & Period & & & $1896-1901$ & $1923-1926$ & $1940-1955$ & $1984-1988$ & $2009-2011$ \\
\cline { 2 - 8 } & Percentage & & & $>15$ & $>20$ & $>20$ & $>20 \%$ & $>15 \%$ \\
\hline Public debt quotation & Period & $1850-1881$ & $1882-1899$ & $1900-1915$ & $1916-1944$ & $1944-1978$ & $1979-1985$ & $1996-2009$ \\
\cline { 2 - 9 } & Percentage & $>40 \%$ & $>60 \%$ & $>80 \%$ & $>100 \%$ & $>100 \%$ & $>100 \%$ & $>100 \%$ \\
\hline
\end{tabular}

Source: Same source as graphs 1, 5, 6 and 7. 


\section{THE DEBT CHAOS INHERITED FROM THE ANCIEN REGIME}

In Section 3.1, we will see how the absolutist governments were irresponsible in their management of public debt. In the twilight of the Ancien Regime, they repudiated previously issued debts and stopped servicing them. In 1814, Fernando VII reneged on external debt. In 1823, he repudiated again the external borrowings issued during the Constitutional Triennium (1820-1823). Moreover, Fernando VII stopped paying the interest on domestic debts in 1826. In Section 3.2, we will analyse how the first Liberal governments did not honour public debt either. Despite the fact that the Finance Minister Count of Toreno restructured the debt in 1834, subsequent Liberal governments were unable to service external debt. We will also see how Minister Alejandro Mon consolidated the short-term debt in 1844. In the fourth section, we will examine the comprehensive debt restructuring carried out by Bravo Murillo in 1850. This rescheduling triggered the protests of foreign bondholders and the shutdown of the European stock exchanges to Spanish securities. This international pressure forced the Spanish government to rectify and García Barzanallana to implement a new debt restructuring after a pact with foreign bondholders.

\subsection{Fernando VII's defaults (1814-1833)}

The absolutist monarch repudiated the loans made previously to the Spanish Treasury and neglected debt service. On the contrary, the Liberal governments of the constitutional periods did acknowledge all existing public securities. This meant a radical difference in fiscal principles between liberals and absolutists. However, in practice, the liberals could neither pay interests due nor redeem the debt. The fiscal irresponsibility of the Spanish Treasury ministers during the first half of the $19^{\text {th }}$ century worsened the debt crisis inherited from the $18^{\text {th }}$ century. This reduced the State's creditworthiness and prevented financial revolution in Spain. Consequently, the Treasury had to continue funding the budget deficits turning to Spanish financiers who charged high interest rates, increasing borrowing costs. The large volume of public debt inherited from the Ancien Regime as well as the irresponsible fiscal management burdened Spanish public finances during the $19^{\text {th }}$ century (see Comín 2004).

The wars against France and England as of 1793 were financed by issuing public debt (vales reales, royal notes), and with loans from the Bank of San Carlos, a national bank created specifically to finance the government. Between 1793 and 1808, the public debt grew from 2019 to 7194 million reals, which is an amount similar to the cost of financing the wars. The issue of vales reales with respect to tax revenue was excessive and the government could not service the royal bonds that were depreciating severely. In 1798, a sinking fund (Caja de Amortización) was created to service this debt. It was 
endowed with some earmarked taxes and the resources from the disentailment of the properties of charities and religious institutions (the desamortización of Godoy). Nevertheless, the sinking fund barely paid back the royal bonds (only 340 million reals), because the Monarch allocated the funds from the Caja de Amortización to finance the war expenses, thereby breaking his promise to set them aside for debt redemption. This was the first default $\left(1^{\text {st }}\right)$ analysed in this paper (Table 2). Although the Liberal finance ministers of the period 1808-1813 (Cortes de Cádiz) tried, they were not able to solve the debt crisis because they had to finance the War of Independence against Napoleon. War expenditures increased the face value of the existing bonds to 11,313 million reals in 1813 . The Spanish governments in Cádiz could not honour the public debt ( $2^{\text {nd }}$ default). Canga Argüelles' debt restructuring plan, during the Courts of Cádiz, again followed the principle of the sinking fund and tried to resort to disentailment to boost Treasury revenues. It was not possible to carry out the plan but it marked the guidelines for later attempts to resolve the debt crisis in Spain.

In 1814, Fernando VII re-established absolutism and repudiated the Dutch debt $\left(3^{\text {rd }}\right)$. This closed international markets to Spanish debt. The bad experience with royal bonds as well as the constitutional and absolutist governments' failure to service internal debt prevented the issuance of public debt on the domestic market. Between 1814 and 1820, internal loans were expensive, especially between 1816 and 1819 when the Treasury's financing needs were high. The Finance Minister, Martín de Garay, tried to address the debt crisis following the strategy used by the Courts of Cádiz. This restructuring failed $\left(4^{\text {th }}\right)$, because insufficient resources were allocated to debt redemption (the State Council vetoed disentailment) and coupon payment (the earmarked tax revenue was small).

In 1820, public debt had grown to 14,021 million reals due to debt issues and the fact that debt interest and arrears on the payments of public expenditures were paid with new securities. The Liberals of the Constitutional Triennium (1820-1823) tried to honour debt commitments for doctrinal reasons. They resorted to foreign borrowing to avoid the crowding out of private investment. Budget deficits were funded through external debt issues (2724 million reals). In 1823, the public debt amounted to 16,700 million reals (Comín 1990; Fontana 1977).

In 1823, after the second absolutist restoration, Fernando VII defaulted $\left(5^{\text {th }}\right.$ default) on the external debt issued by the Liberals and stopped paying interest on domestic debt. Nonetheless, between 1824 and 1830, Fernando VII issued 2860 million reals of external debt with high interest rates. His Finance Minister, López Ballesteros, restructured the debt in $1825\left(6^{\text {th }}\right)$. Shortly afterwards, the government defaulted on Treasury expenditure arrears in 1828, thereby creating an account's default and were even unable to pay the consolidated debt interest because there was no money in the Caja de Amortización, the restored sinking fund ( $7^{\text {th }}$ default). Another unorthodox practice (for the liberal way of thinking of those times) was when 
TABLE 2

OUTSTANDING EPISODES IN PUBLIC DEBT MANAGEMENT IN SPAIN (1798-1988)

\begin{tabular}{|c|c|c|c|}
\hline & Government & Years & Defaults \\
\hline 1 & Carlos II & 1798 & $\begin{array}{l}\text { The Sinking Fund did not repay many } \\
\text { royal notes }\end{array}$ \\
\hline 2 & Cortes de Cádiz & $1812-1813$ & $\begin{array}{l}\text { The liberal governments could not honour } \\
\text { the public debt }\end{array}$ \\
\hline 3 & Fernando VI & 1814 & $\begin{array}{l}\text { Default on external debt and internal } \\
\text { debt's interest coupons }\end{array}$ \\
\hline 4 & Martín de Garay & 1817 & Debt restructuring failure \\
\hline 5 & Fernando VI & 1823 & $\begin{array}{l}\text { Default on external debt and internal } \\
\text { debt's interest coupons }\end{array}$ \\
\hline 6 & Luis López Ballesteros & 1825 & Internal debt restructuring \\
\hline 7 & Luis López Ballesteros & 1828 & $\begin{array}{l}\text { Default on treasury arrears and on } \\
\text { consolidated debt coupons }\end{array}$ \\
\hline 8 & Conde de Toreno & 1834 & $\begin{array}{l}\text { Restructuring of external debt and coupon } \\
\text { arrears consolidation }\end{array}$ \\
\hline 9 & Isabel I & $1836-1845$ & $\begin{array}{l}\text { Default on internal debt's interest } \\
\text { coupons }\end{array}$ \\
\hline 10 & $\begin{array}{l}\text { Agustín Fernández } \\
\text { Gamboa }\end{array}$ & 1841 & $\begin{array}{l}\text { Capitalisation of accrued interest on } \\
\text { consolidated debt }\end{array}$ \\
\hline 11 & Alejandro Mon & 1844 & Consolidation of floating debt \\
\hline 12 & Juan Bravo Murillo & 1851 & Broad rescheduling of public debt \\
\hline 13 & $\begin{array}{l}\text { Manuel García Barza- } \\
\text { nallana }\end{array}$ & 1867 & $\begin{array}{l}\text { Consolidation of passive debts and } \\
\text { accrued coupons. }\end{array}$ \\
\hline 14 & Sexenio democrático & 1871 & Default on interest coupons \\
\hline 15 & Pedro Salaverría & 1876 & $\begin{array}{l}\text { Partial default on coupons and consolida- } \\
\text { tion of outstanding coupons }\end{array}$ \\
\hline 16 & Juan Francisco Camacho & 1881 & Broad rescheduling of public debt \\
\hline 17 & $\begin{array}{l}\text { Raimando Fernández } \\
\text { Villaverde }\end{array}$ & 1900 & $\begin{array}{l}\text { Broad rescheduling of public debt and } 2 \% \\
\text { debt interest tax }\end{array}$ \\
\hline 18 & Alfonso XI & $1915-1919$ & Inflationary tax \\
\hline 19 & Santiago Alba & 1917 & Floating debt consolidation \\
\hline 20 & Juan de la Cierva & 1919 & Floating debt consolidation \\
\hline 21 & José Calvo Sotelo & $1927-1928$ & Two floating debt consolidations \\
\hline 22 & Joaquín Chapaprieta & 1935 & Floating debt consolidation \\
\hline
\end{tabular}


TABLE 2 (Cont.)

\begin{tabular}{|l|l|c|l|}
\hline 23 & José Larraz & 1939 & $\begin{array}{l}\text { Floating debt consolidation and } \\
\text { suspension of debt repayment }\end{array}$ \\
\hline 24 & Franco Regime & $1940-1950$ & Inflationary tax and financial repression \\
\hline 25 & Democracy Regime & $1972-1988$ & Inflationary tax and financial repression \\
\hline
\end{tabular}

Source: Comín (1996).

López Ballesteros managed to redeem public debt through open market operations where he took advantage of the fact that its market price was significantly below the face value. These irregularities committed by López Ballesteros led to the closing of the Paris stock exchange to Spanish securities. This finance minister relaunched the Bank of San Carlos (renaming it the Bank of San Fernando) in 1829, so as to finance the ailing Treasury (Comín 1995). Debt defaults and these irregular operations explain the reduction of the accounting value of the public debt to 5924 million reals in 1830 .

\subsection{Debt restructurings carried out by the first Liberals (1834-1844)}

When the Liberals returned to power in 1833 after the death of Fernando VII, they honoured all the public debts in order to initiate responsible debt management. Nevertheless, the large level of existing debt was unsustainable and prevented them from servicing it. Therefore, in 1834, Count of Toreno $\left(8^{\text {th }}\right)$ restructured and consolidated the outstanding debt. The restructuring affected external debt (except for the debt acknowledged to France, England and the United States by virtue of the 1828 and 1834 treaties). Two-thirds of the external debt was considered «active debt» while the rest was "passive debt» on which interest would not be paid. Toreno's restructuring worsened the debt crisis because the 400 million real borrowing issued to implement it had to be made with a 50 per cent discount (Piernas Hurtado 1901). Besides, the new debt could only be serviced for a year and then coupon payments were defaulted between 1836 and 1845 (Artola 1986, pp. 165-170). Considering this failed restructuring, the market price of the Spanish debt dropped even more, which prevented the issue of new debt on the market because of the enormous discounts this would have required. Default on the debt interest from 1836 onwards worsened the debt crisis even more.

Financing the Carlist War (1833-1841) also aggravated the debt crisis. European stock exchanges were closed to Spanish securities so the war had to be financed with short-term loans from private financiers and the Bank of San Fernando at very high interest rates and through other indirect compensations and businesses for the financiers. The short-term debt also skyrocketed because new securities were issued to meet the accumulation of unpaid interest 
and the delays of the Treasury in paying for the armies' supplies. The progressive Liberals resorted to disentailment of the church's properties (Juan Álvarez Mendizábal in 1836) to solve the debt crisis orthodoxly, selling public assets. In fact, Mendizábal's disentailment allowed for redemption of a large part of the public debt, the volume of which fell from 10,644 million reals to 5691 million reals between 1834 and 1840. However, the disentailment resources were insufficient to redeem all the public debt, thereby leaving the debt crisis unsolved. In fact, between 1836 and 1845, Isabel II's liberal governments defaulted on internal debt interest coupons $\left(9^{\text {th }}\right)$. Therefore, when the Carlist War was over in 1841 , Finance Minister Fernández Gamboa $\left(10^{\text {th }}\right)$ carried out another restructuring, capitalising on the consolidated domestic and foreign debt interests due. To do so, he handed over securities of the new consolidated debt at 3 per cent.

The political instability that followed the Carlist War generated highbudget deficits financed with short-term loans. Consequently, the short-term debt acquired major proportions and was serviced through some earmarked taxes. This left the minister of finance without available resources to pay the rest of the State's expenditures. To free the tax earmarked for servicing the short-term public debt, Alejandro Mon carried out a consolidation of this sum $\left(11^{\text {th }}\right)$ in 1844 . This debt restructuring was essential to prepare the 1845 tax reform because, before removing old taxes, Mon had to liberate them from the government's service of the debt. In July of 1844, Mon restructured the debt exchanging short-term securities in consolidated bonds at 3 per cent at the rate of exchange of 35 per cent ${ }^{4}$. Mon's restructuring extended debt maturity and reduced debt interests but increased the face value of debt (1148 million over the 7673 million that existed in 1844) (Comín and Vallejo 2002, pp. 185-195). This compensated for the reduction of the high coupons paid out on the borrowings used to finance the Carlist War. As part of the rescheduling, Mon signed a cash contract with the Bank of San Fernando that reduced the price of financing the Treasury. These measures allowed him to meet the State's spending and carry out the 1845 tax reform (Comín 2010; Comín and Vallejo 2002, pp. 229-265). Nonetheless, Mon did not resolve the structural debt crisis, which, in reality, meant permanent default. The governments had partially met the domestic debt servicing but the external debt «was abandoned since $1835 »$. The debt crisis was not one of illiquidity but one of insolvency. The public debt level became unsustainable (Piernas Hurtado 1901).

\subsection{A two-staged debt restructuring: Bravo Murillo and García Barzanallana (1851-1867)}

Bravo Murillo's broad debt restructuring $\left(12^{\text {th }}\right)$ was inevitable but it contained significant defects: it was detrimental to the interests of some

\footnotetext{
4 The Treasury handed over 100 nominal reals of new debt for every 35 nominal reals of the old debt.
} 
creditors, overloaded budget expenditures and raised the face value of the public debt. The restructuring was drastic given the magnitude of the debt crisis. The only alternative left for the minister was to declare the Treasury in open bankruptcy, thereby defaulting on public debt. However, this did not make up part of a Liberal finance minister's ideology.

The general restructuring of Bravo Murillo (1851) acknowledged all debts, even all arrears on State payments. It was good judgement to reduce the huge variety of existing securities into two types: State (consolidated) and Treasury (floating or short-term). The old debts, with capital discount, were converted into the State debt while personal and material arrears became Treasury debt. The results of the 1851 restructuring were: (a) a slight reduction of the outstanding debt from 3900 to 3691 million pesetas and (b) a decline of the budget debt burden both due to the decrease in interest rates and the debt face value as well as the moratorium on payment of the new passive debt interest. Foreign debt holders described this restructuring as «disguised bankruptcy». The Paris stock exchange was closed to Spanish securities. Spain ranked as an insolvent country in the international stock exchanges (Comín 1988). In compensation for the discount in the face value and the coupon reduction, Bravo Murillo offered a commitment to service the bonds, which, before 1851, were worth almost nothing in the market.

In fact, the restructuring had not been so dramatic. Bravo Murillo only reduced the interest rate to 33 per cent of the existing debt and he only reduced the face value to 2.2 per cent of the debt. This explains why foreign bondholders did not protest about the reduction in either the interest rate or the nominal of the securities. They rejected three things: (1) reducing the amount of due coupons to half, (2) the condition of passive debt (they would not pay interest for some time) that would acquire part of the debt and (3) the small budget funds that Bravo Murillo earmarked for debt redemption. The international repercussions of this restructuring arose from the speculators' protests - speculators who had acquired at sale price, large amounts of the redeemable and passive debt before the rescheduling (and therefore their coupons were due but had not yet been paid). Later the investors pressed the Spanish State to recognise the old debts and their due coupons for their face value. When Bravo Murillo left the government, the foreign bondholders continued pressuring the Spanish government. Finally, in July 1867, they got García Barzanallana to restructure the debt to suit them just when the next debt crisis came about.

This happened in 1866 when servicing the debt once again became unsustainable because the figure exceeded 30 per cent of budget expenditures. In July of the following year, García de Barzanallana $\left(13^{\text {th }}\right)$ restructured the debt, thereby exchanging passive and redeemable securities and the accrued coupons for consolidated debt at 3 per cent. This was exactly what the foreign bondholders had been asking for. In fact, they accepted a 25 per cent cut in face value. The minister of finance demanded cash 
payment (raising 379 million) in exchange for the new consolidated debt. This meant that the foreign bondholders, so wronged by Bravo Murillo, let Barzanallana reduce the face value of the debt and extend maturity simply to obtain consolidated bonds that paid out interest; they also admitted a 50 per cent reduction in the nominal of the unpaid coupons - which they had denied Bravo Murillo. Barzanallana corrected Bravo Murillo's restructuring but the latter had paved the way. After two restructurings, the Spanish securities had been reduced to three types: consolidated debt at 3 per cent, Treasury debt and Public Works debt. Moreover, they updated the State's liabilities and paid the bondholders regularly...until the next debt crisis arrived during the six-year democratic period.

\subsection{Defaults during the six-year democratic period and Salaverría's restructuring (1868-1876)}

From 1851, budget deficits had been financed with loans from the Caja General de Depósitos (General Savings Bank), issues of domestic debt and during progressive periods, foreign borrowings. Nevertheless, public debt grew more than the accumulated budget deficits because special securities were issued to finance expenditure outside the ordinary budget: building highways, subsidising the railways and compensation to city halls for the disentailment of their land in 1855 (Comín 1988, 1996, pp. 158-165). Debt servicing payments increased creating another debt crisis during the six-year democratic period, when debt became unsustainable; in fact, since 1871, the liberal ministers had been in default on interest coupons $\left(14^{\text {th }}\right)$. To restore debt sustainability another restructuring was carried out by Salaverría $\left(15^{\text {th }}\right)$ in 1876. Salaverría partially resumed payment of debt interest (defaulting 66 per cent of the interest of the 90 per cent of the outstanding debt for five years). This restructuring raised the level of debt through the issue of redeemable debt at 2 per cent to compensate the accrued and unpaid interests. Salaverría's restructuring was an emergency solution to avoid outright default, but it did not restore debt sustainability. In 1879, public debt was 1.65 times the GDP and the debt burden represented 33.3 per cent of budget expenditure (Figures 5 and 6). This level of public debt was intolerable for the Spanish Treasury (Comín 1996).

\section{VOLUNTARY PUBLIC DEBT RESTRUCTURING (1881-1914)}

Bravo Murillo and Salaverría's restructurings were imposed on bondholders and the swaps of old bonds for new were compulsory. On the contrary, Camacho's rescheduling was agreed with bondholders and the swap was voluntary, because bondholders could keep their old bonds. Since then, 
this type of restructuring, which takes advantage of the market conditions to the State's advantage, has predominated.

\subsection{Camacho's negotiated, voluntary debt rescheduling (1881)}

In view of the serious debt crisis, Finance Minister Camacho $\left(16^{\text {th }}\right)$ restructured the debt to simplify the types of securities, diminish the State's indebtedness and reduce the debt burden. This restructuring took advantage of the favourable market situation at the beginning of the 1880s, which permitted a reduction of interest rates and an extension of debt maturity. In December 1881, a law authorised the issue of 1800 million nominal pesetas of bonds at 4 per cent (redeemable in 40 years at a discount of 20 per cent with an interest rate of 5 per cent), to restructure some old securities (some accepted in the swap at face value and others with a discount). Almost all bondholders opted for the exchange. Likewise, Camacho restructured the consolidated debt to equate its face interest rate with European securities. The bondholders of domestic consolidated debt admitted a yield of 1.75 per cent while foreign bondholders initially rejected Camacho's restructuring, demanding a yield of 2 per cent ${ }^{5}$. Camacho's restructuring was successful because it ensured that the interest payment received by bondholders would be for the whole value. Foreign bondholders were guaranteed payment in gold.

The rescheduling was fast and complete and it restored debt sustainability. Camacho's merit was to seize the market opportunity to lower the annual servicing of the redeemable debt (in exchange for a slight increase in face value), and reduce the capital of the non-redeemable debt (at the expense of a small increase in the interest rate). Camacho diminished the level of the public debt from 13,500 million to 6800 million between 1880 and 1883; in relation to GDP, it fell from 152 per cent to 73 per cent. The rescheduling reduced the debt burden from 33.3 per cent to 25.4 per cent of the total budget expenditure between 1879 and 1882, but it went up to 30.4 per cent in 1883. Afterwards, public debt and its service once again increased due to the persistence of the budget deficit, which worsened during the war in Cuba (Figures 5 and 6). The level of the public debt stabilised at around 7000 million pesetas after Camacho's rescheduling. After 1895, the war in Cuba increased the State's borrowing and unleashed another public debt crisis. The debt/GDP ratio was 77.7 per cent in 1890 . After that, it grew from 85.5 per cent to 127.9 per cent between 1894 and 1902. Public debt became unsustainable once again and this new debt crisis was resolved by Villaverde's fiscal austerity package, tax reform and debt restructuring in 1900 (Comín et al. 2006).

5 The finance minister reached an agreement, thereby giving a 0.87 per cent commission to the bondholders of external consolidated debt who opted for swapping and who paid a 50,000 pound sterling commission to the Council of Foreign Bondholders. 


\subsection{Fernández Villaverde's debt restructuring (1900)}

The cornerstone of Fernández Villaverde's fiscal consolidation package was the restructuring of the debt because it reduced government spending. In 1898, the debt burden reached 43 per cent of budget spending, a figure which was unsustainable. Hence, Villaverde $\left(17^{\text {th }}\right)$ restructured the public debt with three measures: (1) the consolidation of the Treasury's debt in redeemable debt, with a maturity of 50 years, (2) the exchange of redeemable debt into non-redeemable debt and (3) the establishment of a 20 per cent tax on domestic debt interests (including the external debt that Spaniards held). Although Villaverde preferred redeemable debt, he relinquished his own ideas and increased the non-redeemable debt from 56 per cent to 81 per cent between 1898 and 1907. The suspension of payback payments and the extension of the maturity of redeemable debt were compensated by the increase in the nominal interest rate. This initially increased debt servicing in budget spending from 43 per cent to 46 per cent between 1898 and 1903. This figure dropped to 28 per cent in 1914.

The novelty of Fernández Villaverde's restructuring was the establishment of the 20 per cent tax on the domestic debt interest (public debt had previously been tax exempt), which reduced the net debt burden (interest paid on minus tax). Villaverde's restructuring showed that the government could ask Spanish bondholders for more than foreign lenders. Since much of the external debt was in Spanish hands, the finance minister asked them to sign an affidavit to convert it into domestic debt. This meant a forfeit for Spanish bondholders because they would no longer receive the interest payment in gold, but in pesetas, and they would be subject to the 20 per cent tax on debt interest. In compensation for the loss, Villaverde offered the bondholders a commitment to service the debt and to maintain its real value by stabilising prices and fighting inflation. Two additional factors increased the debt burden after Villaverde's reform: (1) the State assumed the debts issued by Cuba and the Philippines provinces between 1899 and 1902 and (2) the new debt securities for Villaverde's rescheduling were issued with appreciable premiums so as to compensate the longer maturity, which increased the outstanding public debt.

Villaverde's restructuring temporarily solved the debt crisis, restoring debt sustainability. The existing public debt fell from 13,280 million pesetas to 10,325 million between 1901 and 1914; the debt to GDP ratio diminished from 127.9 per cent to 44.4 per cent between 1902 and 1920. As we have just seen, the debt burden in the budget also fell. The main feature of Villaverde's fiscal policy was the budget surplus (1899-1908), which allowed him to pay off the short-term debt in the Bank of Spain's portfolio. Villaverde's financial orthodoxy was proved when, as Prime Minister in 1903, he presented a bill to implant the gold standard in Spain - a bill which later failed in parliament (Comín 1998, 1999; Comín et al. 2006). 


\subsection{Debt restructuring in the interwar period (1917-1939)}

As we have seen, between 1914 and 1920, the real outstanding public debt fell sharply due to the inflationary tax, the first relevant covert default $\left(18^{\text {th }}\right)$. This new instrument of default replaced the official public debt restructurings of the $19^{\text {th }}$ century. The new formal restructurings were less frequent and more respectful of the subscribers in the $20^{\text {th }}$ century; in fact, they were mere debt consolidations. Therefore, they were not carried out under the threat of debt unsustainability but rather to take advantage of the favourable conditions of the financial markets to consolidate floating debt. These restructurings were optional: when the holders rejected swapping, the Treasury paid off the old debt. Worthy of mention are those restructurings carried out by the following finance ministers: Santiago Alba in $1917\left(19^{\text {th }}\right)$, Juan de la Cierva in $1919\left(20^{\text {th }}\right)$, José Calvo Sotelo in 1927-1928, Joaquín Chapaprieta in 1935 and José Larraz in 1939 (Comín, Martín Aceña and Martorell 2000).

In 1927, Calvo Sotelo $\left(21^{\text {st }}\right)$ consolidated 5225 million pesetas of Treasury bills at 5 per cent in consolidated debt. The following year, the minister swapped non-redeemable for redeemable debt. These restructurings were successful in part because the new debt was exempt from the tax of 20 per cent on the debt interest. Chapaprieta's restructuring $\left(22^{\text {nd }}\right)$ took advantage of market conditions to lower the interest rates on the public debt and to consolidate the Treasury's debt by extending maturity (Comín 1988).

In 1939, Larraz restructured $\left(23^{\text {rd }}\right)$ public debt to reduce interest rates; he also suspended debt repayment until 1946. Larraz took advantage of the low market interest rates that originated from the large monetary supply in the post-war period. Moreover, this restructuring was prepared by the 1939 monetary policy: (a) interest rates of bank discounts at the Bank of Spain were reduced, (b) priority was given to the new bonds for payment of coupons and (c) the government assured the banks' automatic pledging of Treasury bonds at 90 per cent of their face value as well as exemption from stamp duty. After the Civil War, the budget deficit was monetised once again by printing money and pledging public debt by the Bank of Spain. Larraz's debt restructuring reduced the debt service burdens in the public budget (Comín, Martín Aceña and Serrano Sanz 2000).

\subsection{Currency debasement and inflation tax during the Franco regime (1940-1975)}

The historical experience of Spain follows the pattern revealed by Reinhart and Rogoff (2009). When governments cannot issue foreign borrowings they turn to the issue of domestic debt. A consequence of defaulting on external debt in Spain was the growth of domestic debt. Governments then learned that they could default on their domestic creditors more easily than on foreign creditors, using two types of disguised default consisting of inflation tax and 
financial repression ${ }^{6}$. Domestic debt default through inflation was possible when fiat money displaced coinage. The theoretical models do not explain the paradox that governments implemented inflationary monetary policies, which created inflation rates higher than the level that would maximise revenues by seigniorage. Reinhart and Rogoff explained this paradox using the argument that, by means of inflation, governments sought to reduce the real value of domestic public debt ${ }^{7}$. By creating inflation, governments seek to finance their budget deficits by printing money and by defaulting on domestic debt.

In $20^{\text {th }}$ century Spain, the Treasury did without the defaults that had been so protested in the previous century and instead turned to inflation tax. The mechanisms of inflation tax were set up in 1874 when the Bank of Spain was granted the monopoly to issue bank notes in exchange for becoming the Treasury's lender. Finance ministers monetised the budget deficit. This was possible because Spain never belonged to the gold standard; what is more, as of 1883, the peseta was no longer convertible to gold. The budget deficit could be monetised directly. The Treasury asked the Bank of Spain for loans, the latter carried this out by issuing bank notes and increasing the balance of the Treasury's current account. Bills from the Bank of Spain and the banks' current accounts began to predominate over coins in the money supply. This increased the country's monetary base and therefore generated inflation and domestic currency depreciation. Nonetheless, finance ministers did not abuse the monetisation of the deficit except between 1895 and 1899, when the war in Cuba was financed with short-term debt underwritten by the Bank of Spain. In the $20^{\text {th }}$ century, after World War I, Spanish governments resorted to indirect monetisation of the budget deficit via a pledge made by the Bank of Spain to cover the public debt, which had been underwritten by the banks. This triggered an inflationary process that reduced the real value of the domestic debt. In parallel, the domestic debt developed utmost importance due to the reduction of the external debt in that same period, as we have seen. Therefore, from the end of the $19^{\text {th }}$ century on, Spain was able to use inflation tax, which substituted debt defaults and restructurings as a way to solve debt crises. By issuing money, the Spanish Treasury settled its financial woes and reduced real public indebtedness. Inflation tax had three advantages for the finance ministers: (1) the bondholders who suffered money illusion did not notice it, (2) budget deficits could be funded more cheaply and without increasing fiscal pressure and (3) the existing real debt and real interest rates dropped.

Inflation tax was widely used by Spanish governments from 1914 until the 1970s. In the post-Civil War period (1940-1950, $\left.24^{\text {th }}\right)$, it was used abusively

\footnotetext{
${ }^{6}$ These disguised defaults are not included in the Reinhart and Rogoff series, although they are indirectly reflected in the inflationary crisis and in banking regulation.

${ }^{7}$ During the intense inflationary processes after the First World War (in Germany, Greece, Italy and Norway), in the Second World War (Japan), and in the 1980s (Argentina, Brazil and The Philippines), the magnitude of domestic public debt was at least as large as the monetary base.
} 
when, as we have seen, real debt interest rates were negative and real debt value went down. Nevertheless, after the period of high inflationary tax of the years 1972-1988 $\left(25^{\text {th }}\right)$, Spanish investors did not suffer from money illusion. From then on, the government had to raise the nominal interest rate of the State's debt when there was inflation because the investors wanted to maintain the real interest rate. Moreover, political democratisation and the liberalisation of the Spanish economy from 1977 forced the government to manage the debt responsibly.

Financial repression was another unorthodox way of financing the public sector that avoided explicit debt crises during the Franco regime ${ }^{8}$. Financial repression forced Spanish savers to lend to the government at below-market interest rates via the following measures: caps on interest rates, purchases of public debt by stated-owned banks, financial regulation requiring banks and savings banks to hold high portfolios of public debt and tax incentives for savers to buy bonds. The compulsory investment coefficients in public debt and the INI bonds had forced banks and savings banks to finance public and private investments under the Development Plans (1964-1974) (see Comín and Vallejo 2009). This compulsory bank financing of extra-budgetary public investments prevented the emergence of budget deficits and public debt issuance in market conditions during the Franco regime. This financial repression involved an implicit tax to be paid by depositors of banks and savings banks that subscribed public debt, because the yields they received were lower than those available on the market. It was a covert repudiation of the savers' funds (Comín 2007).

\section{THE DEBT CRISIS DURING THE DEMOCRATIC PERIOD (1976-2012)}

According to Reinhart and Rogoff (2009), Spain was one of the last countries in Europe to graduate from serial default. This graduation took place during democracy.

\subsection{Graduation in responsible debt management during the democratic period}

At the end of the $20^{\text {th }}$ century default - either outright or disguised - on the Spanish public debt was unthinkable. Responsible public debt management was set as a goal by the Spanish government in 1978 but it was not actually implemented until 1987, a year after Spain became a member of the EEC. In an initial phase (the period of political transition to democracy from

8 Financial repression was «the more subtle way of debt restructuring», according to Reinhart and Sbrancia (2011) and it was implemented, jointly with inflation, in advanced countries between 1945 and 1980, and subsequently in emerging countries, to reduce «lofty mountains of public debt». 
1978 to 1986), financial liberalisation tried to put an end to the financial repression that had helped to fund the government under Franco, in conditions that were advantageous in relation to the market. During the transition to democracy, the waiver of financial repression demanded changes in public debt policy which had sought three goals since 1978: (1) to bring public debt issuances closer to financial market conditions, (2) to place the debt between the public and non-financial institutions and (3) to dispense with recourse of the Treasury to the Bank of Spain funding. The first democratic governments tried to avoid financial repression that concealed the actual financial burden of the public budget. To create a domestic debt market, from 1978, the following reforms were introduced: (a) debt issues were regularised and new placement methods, such as auctions, were adopted and (b) new debt securities were created and they were traded with new financial technologies, such as account entries and the telephone market. Likewise, democratic governments pursued monetary discipline by trying to finance budget deficits without resorting to inflation tax. In the 1980s, governments tried to wean monetary policy away from fiscal policy but they could not get rid of old budget funding habits until 1987: (1) banks and savings banks continued to be compelled to subscribe the larger part of the public debt, (2) the Treasury continued to be financed unorthodoxly: loans from the Bank of Spain to the Treasury increased, the obligatory investment ratios were increased as were the cash ratios of banks and savings banks, (3) tax-free public debt was issued and (4) short-term public debt placed in both public and private banks was monetised.

In fact, between 1977 and 1987, higher market interest rates led the Treasury to resort to short-term loans from the Bank of Spain to finance budget deficit. This increased the monetary base. To avoid excessive growth of the monetary supply, they resorted to liquidity drains until 1982, and afterwards to increasing the banks' obligatory ratios (investment and cash ratios). First, from 1977 to 1982, the Bank of Spain issued short-term debt to offset the effects of the Bank of Spain's loans on the money supply; this worsened the Bank of Spain's profits and left no monetary policy autonomy. Second, between 1983 and 1987, they used the obligatory ratios of private banks (financial repression) to control the money supply more effectively. Spain's entry into the EEC in 1986 was central to the modernisation of public debt management. Since 1987, the objectives of Treasury funding were: (a) implementation of the prohibition of budget deficit financing by the Bank of Spain, established by the Treaty of the European Union, (b) extending debt maturity while retaining a percentage of short-term debt so that the Treasury could benefit from drops in interest rates, (c) public budget funding without any privileges, (d) institutional and technical modernisation of the debt market ${ }^{9}$ and (e) placing the debt among private and non-financial institutions.

9 Modernisation started in 1987 with the creation of the Account Entries System as well as the development of the secondary public debt market (see Comín 1996). 
In the same line, we can highlight the following measures. Since 1989, the gradual reduction in the compulsory investment ratio of banks in Treasury bills began (which was 11 per cent of the bank's liabilities). To avoid the inflationary financing of the budget deficit by the Bank of Spain, monetary policy independence began after Spain entered the European Monetary System in 1989. Entering the EEC demanded free movement of capital and membership to European monetary institutions. Therefore, in the 1990s, it was impracticable to default on the public debt by reducing its real value through deficit monetisation, because of Spain's membership of the European Monetary System and, subsequently, the Euro system, but also because of the absence of money illusion on the part of both Spanish and foreign investors. In summary, entering the European Monetary System brought an end to the tradition of financing budget deficits by increasing the monetary base by the Bank of Spain and bank underwriting of public debt at low interest rates, because of the disappearance of the compulsory investment ratios. Finally, the need to reduce the budget deficit/GDP ratio and to contain the growth of the debt/GDP ratio, imposed by the monetary convergence criteria of Maastricht, reduced the Spanish government's fiscal autonomy, which, since 1994, cut the budget deficit and controlled public debt growth, achieving the goal of entering the Euro system.

\subsection{The mirage of the euro and the Eurozone debt crisis}

At the beginning of the $21^{\text {st }}$ century, euro membership reduced the Spanish public debt risk premium practically to zero vis-à-vis German bonds. Cheap credit led to enormous external indebtedness of the private sector in Spain to finance the consumption of households and real estate investment. Financial markets assumed that Spain lacked country risk (or that it was as small as in Germany). The mirage lasted until the outbreak of the Greek debt crisis in 2010 when, once again, the existence of two Europes surfaced: rich, industrialised Central Europe and poor, peripheral South Europe. Since the financial markets make differentiations by large regions, classified by acronyms, Spain was immediately incorporated into the group of peripheral European countries with a public debt crisis. When this happened, technically there was no public debt crisis in Spain. Nonetheless, the markets associated Spain with those countries that did indeed have a public debt crisis.

Membership of the euro exposed Spain to the contagion effect of the peripheral countries' public debt crisis. The Euro system put Spain under a restrictive monetary policy, in 2011, decreed by the European Central Bank, which would delay Spain's exit from the economic crisis, consequently preventing reduction of the public deficit. Finally, the European Central Bank's loans to Spanish banks were at higher interest rates that were promptly demanded at maturity. In summary, in the autumn of 2011, the Spanish 
public debt crisis was not so much a result of the fiscal ratios as of the poor expectations surrounding Spain's recovery from the economic crisis, delayed by the Euro system's restrictive policy.

The debt crisis in Spain that began in 2010 reminds us of those that developing countries had suffered in previous decades. It is difficult to know a country's safety threshold or level of tolerance (the debt/GDP ratio that means a high risk of default on debt), but much depends on its previous history of default on debt and inflationary processes. According to Reinhart and Rogoff (2009), the worse the history (of being a defaulter) the less the capacity of governments to tolerate the debt. That is, to continue borrowing on the international markets without increasing the spreads and without creating a crisis of confidence among investors. Although it seems like a paradox, the countries that have a higher «debt default risk» are precisely the ones who get most into debt on the international markets, in absolute terms, and above all, in relation to foreign currency earnings from exports.

At the beginning of 2012, the explanation for Spain's high public bond spread in comparison with Germany was not the actual level of outstanding public debt but the worsening of the economic recession and the huge needs of recapitalisation of the country's banking sector, whose restructuring had been delayed with respect to other European countries. Sooner or later the Spanish government would have to bailout the banks and savings banks, whose assets (mortgages and public bonds) were plummeting because of the economic crisis. The almost inevitable bank bailout would worsen the Spanish budget deficit and more debt would have to be issued to fund it. Unless the European Union agreed to bailout Spanish banks directly, the scale of the situation would bring budget deficit and public debt/GDP ratios to unsustainable levels, as had happened in Ireland in 2009. The austerity measures imposed by the European Commission (tax rises and spending cuts) would deepen the economic recession in Spain, deteriorating the budget balance even more. As had happened in Greece, Portugal and Ireland, this European restrictive fiscal policy would be self-defeating. Without economic growth and an improvement in the competitiveness of the Spanish economy, the level of public debt would rise and eventually the country would need a bailout by the European Commission, the European Central Bank and the International Monetary Fund, as had been the case of other Eurozone peripheral countries. Only a shift in the European Commission and European Central Bank's fiscal and monetary policies could save the Spanish State from falling into another deep public debt crisis (Krugman 2012; Roubini and Greene 2012; Wolf 2012).

Countries that incurred repudiations and recurrent defaults of foreign debt acquired a greater «debt intolerance», meaning that they reached default situations with low public debt/GDP ratios. Several defaults that took place between 1970 and 2008 occurred in countries with an external debt level below 60 per cent of GDP. Debt intolerance is determined by domestic 
institutional factors such as political corruption, but also by international factors, such as the pro-cyclicality of capital flows into underdeveloped countries. During economic crises, imports of capital stopped flowing into developing countries, so their governments were forced to implement strict fiscal discipline, thereby exacerbating economic depression. The reason was that these countries could not continue borrowing to finance fiscal stimulus policies, because international investors knew that raising budget deficits would lead these countries, already at the threshold of public debt intolerance that would prevent them from servicing it, to default. Therefore, according to Reinhart and Rogoff, the international financial markets and rating agencies question the financial solvency and ability to repay the debt of such developing countries at debt/GDP levels well below those of advanced economies. Even with better fiscal statistics, the international markets attribute increased default risk to countries with poor historical records in managing debt and, therefore, demand higher interest rates. This applies, of course, to the debt crisis of the Eurozone peripheral countries, including Spain since 2010.

\section{CONCLUSIONS}

The Spanish case confirms the main hypothesis of Reinhart and Rogoff (2009) regarding the history of public debt crisis, although they underestimate the number of debt crises, their duration and depth in modern Spain. This paper highlights the following findings.

With regard to the time profile, short-term borrowing and external debt enhanced the risk of a public debt crisis, particularly during the $19^{\text {th }}$ century, when short-term debt could not be rolled over and external debt coupons could not be paid. In the $20^{\text {th }}$ century, the situation reversed and domestic and redeemable debts were more important, especially during the Franco regime.

In relation to debt defaults, insolvency problems arose when Spanish governments were unable to repay the public debt or pay its coupons. Like other countries that had incurred in serial default, Spain tended to overborrow, leaving the country vulnerable to debt crisis. In Spain, most outright defaults ended up being partial defaults.

Regarding inflation tax, default through inflation became commonplace when fiat money displaced coinage in the $20^{\text {th }}$ century. Shut out from international capital markets and facing collapsing revenues, Franco's governments had resorted to inflation tax and financial repression. Governments defaulted on domestic debt through unanticipated inflation. Forced by financial repression banks and savings banks lent a large amount of their assets to the State, which thereby enjoyed a lower interest rate than in a liberalised capital market.

With regard to the consequences of debt crisis, defaults endangered the creditworthiness of the Spanish Finance Ministry. To solve debt crises, 
governments were forced to follow disciplined fiscal policies. However, austerity measures intensified economic recessions and created a debt trap, as has been the case since $2008^{10}$.

Finally, concerning the origins, historically debt crises in Spain reflected a rapid increase in the outstanding public debt as occurred in the politically turbulent periods: the first half of the $19^{\text {th }}$ century and various episodes between 1850 and 1940 (the progressive two-year period, the six-year democratic period, the two Independence Wars in Cuba, the Moroccan War and the Civil War ${ }^{11}$. Before the democratic reforms of 1977-1978, budget revenues and public spending were inelastic to GDP, so economic recessions did not produce debt crisis. On the contrary, the fiscal crises of the democratic period after Franco's death were triggered by economic crises. Debt crises were triggered by the establishment of the welfare state, through progressive income tax and unemployment benefits. The economic recession of the 1970s was worsened by the political transition to democracy. The 1993 and 2008 debt crises were generated entirely by economic factors. In any case, the fiscal crisis that started in 2008 did not become a public debt crisis until May 2010, triggered by contagion from the Greek crisis, although the size of the Spanish debt was small.

\section{REFERENCES}

Artola, M. (1986): La Hacienda del siglo XIX. Progresistas y moderados. Madrid: Alianza. CARRERAS, A., and TAFunELl, X. (coords.) (2005): Estadísticas históricas de España. Siglos $X I X-X X$. Bilbao: BBVA Foundation.

Coggan, P. (2012): Paper Promises. Debt, Money and the New World Order. New York: Public Affairs.

Сомín, F. (1988): Hacienda y Economía en la España Contemporánea, 1800-1936, Vol. II, La Hacienda Transicional (1875-1935). Madrid: Instituto de Estudios Fiscales.

Сомín, F. (1990): Las Cuentas de la Hacienda Preliberal en España (1800-1855). Madrid: Banco de España.

Comín, F. (1995): «La Deuda pública y la formación del Sistema Bancario en España durante los siglos XIX y XX», in P. Tedde, and C. Marichal (eds), La formación de los bancos centrales en España y América Latina (siglos XIX y XX). Madrid: Banco de España, vol. I, pp. 49-79.

Coмín, F. (1996): Historia de la Hacienda pública, II, España (1808-1995). Barcelona: Crítica.

Comín, F. (1999): "La reforma en la Hacienda de Fernández Villaverde», in P. Tedde (ed.), Economía y Colonias en la España del 98. Madrid: Síntesis, pp. 235-260.

Сомín, F. (2004): «La metamorfosis de la Hacienda (1808-1874)», in J. Torras (ed.), Josep Fontana. Historia y proyecto social. Barcelona: Crítica, pp. 31-101.

Comín, F. (2007): «Spanish Savings Banks and the Competitive Cooperation Model (1928-2002)». Revista de Historia Económica. Journal of Iberian and Latin American Economic History, XXXV, 2. pp. 199-229.

10 According to Coggan (2012, pp. 231-232).

11 It was a «war debt», as Graeber (2011, pp. 365-366) pointed out, referring to the U.S. debt since 1790 . 
Comín, F. (2008): «Las economías y los economistas españoles durante la guerra civil española y la posguerra: una introducción», in E. Fuentes Quintana, and F. Comín (eds), vol. I, pp. 7-189.

Сомín, F., and Vallejo, R. (2009): «Los Programas de Inversiones Públicas (1964-1976): ¿El instrumento presupuestario al servicio de los Planes de Desarrollo?», in J. de la Torre y M. García Zúñiga (eds.), Entre el Mercado y el Estado. Los planes de desarrollo durante el franquismo, Pamplona, Universidad Pública de Navarra, pp. 89-145.

Comín, F. (2010): «Public Finance and the Rise of the Liberal State in Spain, 1808-1914», in J. L. Cardoso, and P. Lains (eds), Paying for the Liberal State. The Rise of the Public Finance in Nineteenth-Century Europe. Cambridge: Cambridge University Press, pp. 214-250.

Comín, F. (2011): «Política y Economía: los factores determinantes de la crisis económica durante la Segunda República (1931-1936)». Historia y Política 26, pp. 47-79.

Сомín, F., and DíAz, D. (2005): «Sector público administrativo y estado del bienestar», in A. Carreras, and X. Tafunell (coords.), vol. II, pp. 873-964.

Comín, F., and López, S. (2008): «La Hacienda del Gobierno de la República Española (1936-1939)», in E. Fuentes Quintana, and F. Comín (eds), vol. I, pp. 851-899.

Comín, F., and Vallejo, R. (2002): Alejandro Mon y Menéndez. (1801-1882). Pensamiento y Reforma de la Hacienda. Madrid: Instituto de Estudios Fiscales.

Comín, F.; Martín-Aceña, P., and Serrano sanz, J. M. (eds) (1997): La Hacienda en sus ministros. Franquismo y democracia. Zaragoza: Prensas Universitarias de Zaragoza.

Comín, F.; Martín-Aceña, P., and Martorell, M. (eds) (2000): La Hacienda desde sus Ministros. Del 98 a la Guerra civil. Zaragoza: Prensas Universitarias de Zaragoza.

Comín, F.; Martín-Aceña, P., and Vallejo, R. (eds) (2006): La Hacienda por sus Ministros, La etapa liberal de 1845 a 1899. Zaragoza: Prensas Universitarias de Zaragoza.

Fontana, J. (1977): La Revolución Liberal (Política y Hacienda, 1833-1845). Madrid: Instituto de Estudios Fiscales.

Graeber, D. (2011): Debt. The first 5,000 Years. New York: Melville House.

Krugman, P. (2012): «El suicidio económico de Europa». El País, 22 de abril.

Martín-Aceña, P. (2004): «La Economía Española de los años 1930», in S. Juliá (coord.), La República y la guerra civil. Madrid: Espasa Calpe, pp. 356-443.

Martín-Aceña, P., and Comín, F. (1991): INI. 50 años de Industrialización en España. Madrid: Espasa Calpe.

Martín-AceÑA, P., and Pons, M. Á. (2005): «Sistema monetario y financiero», in A. Carreras, and X. Tafunell (coords.), vol. II, pp. 645-706.

Martorell, M., and Comín, F. (2008): «La Hacienda de guerra franquista», in E. Fuentes Quintana, and F. Comín (eds), vol. I, pp. 901-937.

Piernas Hurtado, J. (1901): Tratado de Hacienda Pública y examen de la española. Madrid.

Prados de la escosura, L. (2003): El progreso económico de España (1850-2000). Bilbao: BBVA Foundation.

Fuentes Quintana, E., (dir.) and Comín F. (coord.) (2008): Economía y Economistas Españoles en la Guerra Civil. Barcelona: Galaxia Guternberg /Círculo de Lectores y RACMYP.

Reinhart, C. M., and Rogoff, K. S. (2009): This Time is Different. Eight centuries of Financial Folly. Princeton: Princeton University Press.

Reinhart, C., and Rogoff, K. S. (2010): «Growth in a Time of Debt». NBER Working Paper, 15639.

ReinHart, C. M., and Sbrancia, B. (2011): «The Liquidation of Government Debt». NBER Working Paper, 16893. 
Reinhart, C. Reinhart, V. R., and Rogoff, K. S. (2012): «Debt Overhangs: Past and Present». NBER Working Paper, 18015.

Roubini, N., and Greene, M. (2012): «Desperately Seeking a Bailout for Spain and its Banks». Financial Times, May10.

Wolf, N. (2012): «Crises and Policy Responses within the Political Trilemma: Europe, 1929-1936 and 2008-2011». EHES Working Paper, 16. 